\title{
Community structure of mussel beds at deep-sea hydrothermal vents
}

\author{
Cindy Lee Van Dover* \\ Biology Department, College of William \& Mary, Williamsburg, Virginia 23187, USA
}

\begin{abstract}
Definition of biogeographic provinces, patterns of species distributions on local and regional scales, species richness, and relative abundances are all basic ecological measures, yet they are largely unknown for deep-sea hydrothermal vent ecosystems. Without an appreciation of biogeographic and biodiversity patterns, it is difficult to understand the evolutionary and ecological processes that underlie species distributions. To begin to address these issues, species composition, species richness, diversity, abundance, and recruitment patterns were studied within mussel beds at 3 remote hydrothermal fields on the southern East Pacific Rise (SEPR). Two closely spaced fields (within $1 \mathrm{~km}$ ) were hydrothermally active and shared the most abundant taxa. The mussel bed communities at these fields could be differentiated primarily by the relative abundances of species rather than by species composition. A third field was in a waning stage of hydrothermal activity. Productivity, biomass, and abundance of invertebrates associated with mussel beds at this third field were low, and the species list was a small subset of that found at the active fields, subsidized by several nonvent deep-sea taxa. Based on abundances of smallest size classes, recruitment of mussels and of several other dominant invertebrate species was high at the active sites. At the waning vent field, no recruitment was observed, except within the population of ophiuroids. Most of the species found within the SEPR mussel beds belong to species previously described from vent sites north of the equator, indicating that there is a single hydrothermal biogeographic province extending along the East Pacific Rise for more than 30 degrees of latitude. There were no shared species between SEPR mussel beds and a Mid-Atlantic Ridge (MAR) vent mussel bed and species richness was more than twice as high at the active SEPR mussel beds than at the Mid-Atlantic Ridge mussel beds. As biogeographic provinces are defined and robust measures of species diversity accumulate for vent habitats on the East Pacific Rise and Mid-Atlantic Ridge, vent ecologists will be able to place the biogeography and biodiversity of vent faunas within the context of the regional and global biogeographic and diversity patterns observed in terrestrial and other marine ecosystems.
\end{abstract}

KEY WORDS: Hydrothermal vent $\cdot$ Diversity $\cdot$ Mussels $\cdot$ Bathymodiolus $\cdot$ Biogeography $\cdot$ Community structure

Resale or republication not permitted without written consent of the publisher

\section{INTRODUCTION}

Description of the structure of a community results in a suite of characters that may be used in comparative studies of diversity and biogeography. These characters include species composition, number of species (species richness), and relative abundance and size-

*E-mail: cindy_vandover@wm.edu frequency distributions of individuals. From these descriptive building blocks, patterns of species distributions can be discerned, and underlying physiological, ecological, evolutionary, and historical processes may be invoked (Underwood et al. 2000). Community structure of intertidal and subtidal communities at the local scale has been the focus of marine ecological studies over the past few decades, with emphasis on manipulative experiments that test the relative importance of a variety of biotic and abiotic factors in determining local 
characteristics (e.g. Connell 1972, 1975, Paine 1974, Menge \& Sutherland 1976, Sousa 1979a,b, Underwood 1984, 2000, Underwood \& Petraitis 1993). This body of work includes an appreciation of scale, both temporal and spatial, as an important context for understanding the generality of interpretations (e.g. Underwood et al. 1983, Ault \& Johnson 1998, Schlacher et al. 1998, Archambault \& Bourget 1999, Petraitis \& Latham 1999). In recent years, there has been a re-evaluation of the significance of historical, geographical, and phylogenetic perspectives on diversity and community structure (e.g. Ricklefs \& Schluter 1993, Losos 1996) at temporal and spatial scales that are expanded beyond contemporary and local measures. Preliminary studies of ecological communities must thus aspire to a quantitative description of community structure over a variety of spatial scales to discern local patterns and to develop testable hypotheses regarding processes underlying these local patterns. They must also anticipate a larger view toward defining and understanding regional- and global-scale variation in community structure and the underlying motifs (e.g. Cornell \& Karlson 1996, Caley \& Schluter 1997). For this analysis of community structure to be meaningful, the data must be collected from comparable communities using comparable methods in all regions of study (Underwood \& Petraitis 1993).

While there may be infinite ways of parsing marine communities to obtain useful and interesting comparisons, a fundamental division is between photoautotrophic and chemoautotrophic communities. In such a comparison, the most basic of questions can be asked: How do patterns and processes observed in communities where photosynthesis dominates apply in communities where the energy base is not derived directly from sunlight but by microbial oxidation of sulfide and other reduced inorganic compounds? To begin to address this question, Van Dover \& Trask (2000) undertook a descriptive comparison of community structure in an intertidal mussel bed on the southcentral Alaskan coast and a deep-sea (1700 m) hydrothermal vent mussel (Bathymodiolus azoricus) bed on the Mid-Atlantic Ridge. There was $100 \%$ non- overlap in species and genera between the 2 sites, and observed species richness within the Atlantic vent mussel bed (28 species) was less than half that of the intertidal mussel bed (64 species), but comparisons of rank abundances and higher-level taxonomic composition (i.e. proportions of crustaceans, polychaetes, and mollusks within species lists) were similar between vent and intertidal mussel bed invertebrates. The Shannon index of diversity $\left(H^{\prime}\right)$ within the vent mussel beds fell within the range of values reported in the literature for intertidal mussel beds (Van Dover \& Trask 2000).
Intertidal mussel beds provide additional context for appreciation of the scope of the questions to be addressed here. In rocky intertidal settings, mussel beds typically represent continuous or semi-continuous linear bands made up of a mosaic of mussel sizeand age-structures resulting from a variety of biotic and abiotic processes. For a given quality of mussel bed habitat, diversity and species richness are not significantly different across tens of kilometers (e.g. Lintas \& Seed 1994, Svane \& Setyobudiandi 1996). Community structure of the associated invertebrate fauna is sensitive to mussel age- and mussel size-structure (e.g. Tsuchiya \& Nishihira 1985). Community structure varies more dramatically when invertebrates associated with mussel beds of different coasts are compared. Species richness can differ by as much as a 5fold along different coast lines (e.g. 56 species associated with mussel beds [Mytilus edulis] of North Wales versus 270 species associated with mussel beds [M. californianus] of the California coast: Seed 1996). These observations help to define the scales of ecological dynamics (e.g. larval transport and recruitment) and evolutionary processes (e.g. isolation and radiation) in open shallow-water marine systems. The local species list in an intertidal mussel bed is a subset of the regional species pool; a regional species pool can extend along tens to hundreds of kilometers of coastline in the absence of a hydrographic barrier.

At issue within vent ecosystems is the definition of local and regional scales. Unlike intertidal zones, vent habitats are isolated and ephemeral. One might predict that dispersal and colonization dynamics in the deep sea result in a community structure that varies more over shorter distances than in intertidal systems. Were we to find similar scales and patterns of variation in deep-sea hydrothermal vent communities as in intertidal communities, we might hypothesize that similar dynamic processes influence community structure.

In this study, I continue the characterization of community structure in hydrothermal systems, this time within Pacific rather than Atlantic vent mussel beds (Bathymodiolus thermophilus rather than B. azoricus), and with attention to heterogeneity within and between vent fields and to variation over the hydrothermal cycle. Mussel bed habitats are structurally more similar to each other across ocean basins than any other habitat so far observed at vents. They consistently occupy hydrothermal settings where temperature excursions rarely exceed 10 to $15^{\circ} \mathrm{C}$. The mussels themselves provide an integrated measure of the productivity of the mussel bed (tissue dry-weight:shell length), allowing preliminary analysis of the correlations of abundance and species richness with productivity. Vent mussel beds exist as isolated patches, usually no more than 50 to $100 \mathrm{~m}$ in maximum dimension 
(Hessler et al. 1988, Van Dover pers. obs.). While vent ecologists have yet to define vent mussel bed distributions, they often occur as multiple small beds within a larger, linear vent field (up to $1.5 \mathrm{~km}$ in length). Vent fields may be separated by tens to hundreds of kilometers, and are defined operationally by investigators. In this study, I use the term vent field to imply that the hydrothermal fluids and fluid flow within a vent field are related, while fluids and fluid flow between vent fields are independent. I assume that discontinuous hydrothermal systems associated with different eruptive events are hydrologically independent.

Like hydrothermal systems in general, mussel beds pass through a hydrothermal cycle, beginning with initial colonization, progressing to well-developed beds with adult mussels stacked on top of each other to form mounds of $\sim 0.5 \mathrm{~m}$ relief, and expiring as waning systems in which a large proportion of the mussels are dead and where those mussels that survive no longer produce byssal threads and lie unstacked (Van Dover pers. obs.). Stages of the hydrothermal cycle reflect the waxing and waning of hydrothermal flow; sulfide concentrations and other hydrothermal chemistry flowing through the mussel bed decrease to zero as the vent shuts down. Cycle duration can vary even within a vent field, due to patchy and stochastic tectonic events that alter fluid flow and to subsurface mineralization that clogs conduits (Hessler et al. 1985, 1988, Fustec et al. 1987). It is impossible to give an average lifetime for a vent mussel bed, but repeated observations of mussel beds and mussel growth curves indicate that lifetimes of at least 10 to $20 \mathrm{yr}$ are not uncommon. A time-series study of 3 discrete mussel beds of known age within the $9^{\circ} 50^{\prime} \mathrm{N}$ hydrothermal field on the East Pacific Rise has been initiated (Van Dover unpubl. data), but here I use a chronoseres approach to examine how mussel bed communities respond to reduction in vent fluid flow by sampling beds that are contemporaneously at different stages of the hydrothermal cycle. Because the associated invertebrate macrofauna of mussel beds ultimately relies on chemoautotrophic production through either symbiotic or free-living chemoautotrophic bacteria, we can relate community structure to measures of chemoautotrophic productivity.

In this study of vent mussel bed community structure, I specifically address the following questions: (1) How does community structure vary within a vent site and between vent sites of similar habitat quality occurring at independent hydrothermal fields that are close to each other (within $850 \mathrm{~m}$ )? (2) How does community structure differ in waxing versus waning hydrothermal sites? (3) How do measures of community structure relate to measures of productivity? (4) Is there a difference in community structure in Atlantic versus Pacific vent mussel beds, and how does commu- nity structure in vent mussel beds compare to that of intertidal mussel beds?

This is the first report to detail community composition within any southern East Pacific Rise hydrothermal vent habitat. The closest well-studied vent communities (Hessler et al. 1988) are on the Galápagos Spreading Center near the equator, roughly $3500 \mathrm{~km}$ away. The work reported here, combined with the Atlantic and intertidal data, provides building blocks toward defining patterns of diversity and biogeography within the global system of deep-ocean hydrothermal vents and toward developing an understanding of historical and geographical processes that underlie these patterns.

\section{MATERIALS AND METHODS}

Replicate samples of mussels and their associated fauna were collected using the submersible 'Alvin' during February 1999 from the Animal Farm, Oasis, and Rehu Marka vent fields on the southern East Pacific Rise between $17^{\circ} 24^{\prime}$ and $18^{\circ} 37^{\prime}$ S (Fig. 1).

The biomass of the fauna at these fields was dominated by the mussel Bathymodiolus thermophilus (Fig. 2), which hosts sulfur-oxidizing, chemoautotrophic, endosymbiotic bacteria. The mussels occupied low-temperature $\left(<10^{\circ} \mathrm{C}\right)$, diffuse-flow zones associated with cracks in lobate basalt lavas. Sampling dates, 'Alvin' dive numbers, geographical coordinates, and depths are summarized by vent field in Table 1 . Within each field, multiple sites were visited and within each site 1 or more samples were collected. Site designations had no a priori significance and were operationally defined as locations within fields between which the submersible had to undertake a transit of more than $10 \mathrm{~m}$. The northern fields, Oasis and Rehu Marka, are separated from each other by $850 \mathrm{~m}$ and from the southern field (Animal Farm) by $133 \mathrm{~km}$. The distance between sites within Oasis and Rehu Marka was $\sim 45 \mathrm{~m}$. The 2 Animal Farm sites were separated by $\sim 15 \mathrm{~m}$. Mussel beds at the 3 fields ranged in maximum dimension from 50 to100 $\mathrm{m}$.

Discrete, qualitative 'scoop' samples (1 to $10 \mathrm{l}$ of mussels per sample) were collected using a kevlarlined scoop and stored in 6 lidded boxes on the 'Alvin' work basket. The scoop technique is 'sloppy', inevitably resulting in loss of individuals. While valuable for measures of cumulative species richness as sample volume accumulates, the abundance data is less reliable for detailed comparisons of within- or betweensite diversity measures. To rectify this sampling problem, a quantitative 'pot' sampler (Fig. 3) was constructed from a 12 qt (11.35 l) kitchen stock pot lined with a kevlar drawstring bag (26 cm diameter) and 


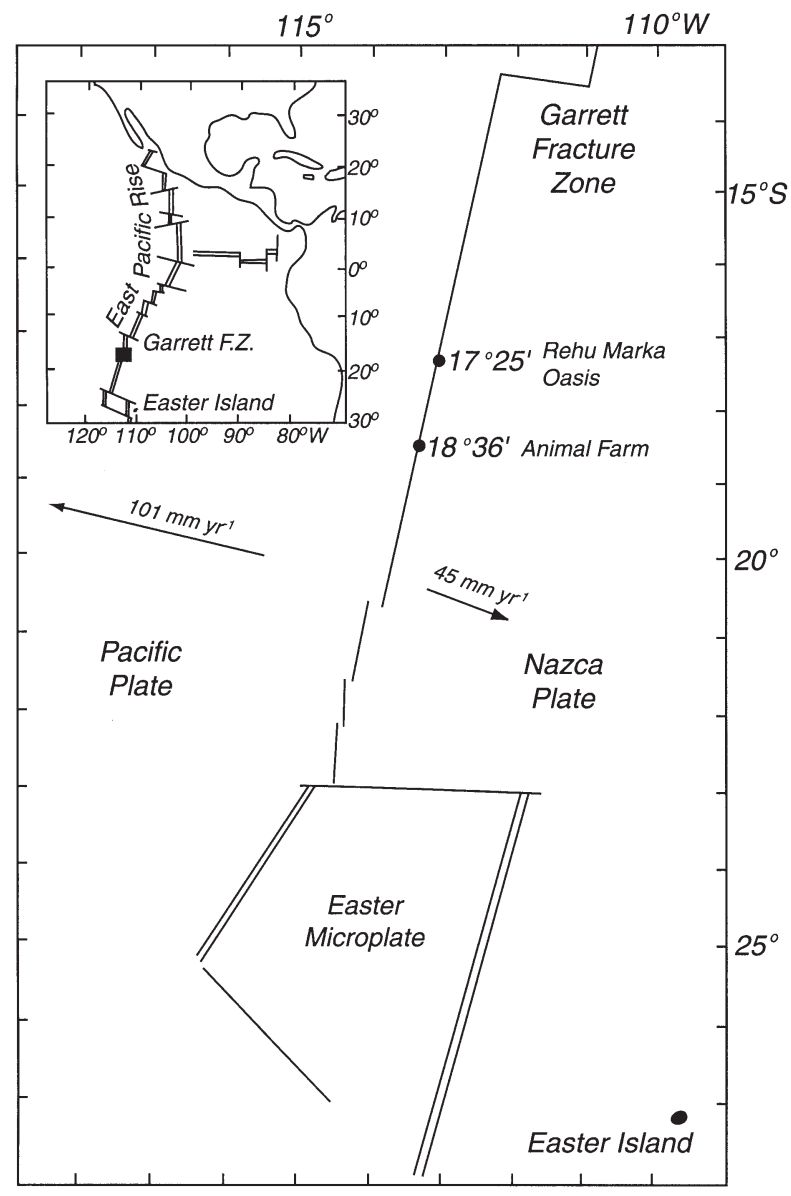

Fig. 1. Location of the vent fields on the southern East Pacific Rise. Arrows indicate direction of spreading and are annotated with spreading rate. Inset illustrates the larger geographic context of the study area (black rectangle) and the East Pacific Rise

fitted with a rotating t-handle and hardware for closing the drawstring. The pot, placed over a mussel clump, samples a variable mussel volume over a constant area of $531 \mathrm{~cm}^{2}$. Once the bag has been cinched up, the pot is placed in a quiver (plastic bucket) on the submersible basket to prevent any loss of mussels. Because the quantitative sampler was under development and sampling opportunities were limited, only a small number of quantitative samples were collected.

At Animal Farm, multiple qualitative scoop samples were taken from each of 2 closely spaced (within meters) sites. At Oasis, quantitative and qualitative samples were paired at 2 different sites within the vent field, and 4 qualitative samples were collected at 4 other haphazardly selected sites along the length of the field. At Rehu Marka, the quantitative sampler had been modified sufficiently so that 2 to 3 quantitative samples were collected from each of 2 sites. This was supplemented by 1 qualitative sample at each site. Except where I explicitly investigate the quantitative differences between Oasis and Rehu Marka and within Rehu Marka sites, all analyses of abundance and species richness discussed below are based on a combination of qualitative and quantitative samples.

Once on deck, mussels were washed 3 times in filtered seawater and the washings were passed through a $250 \mu \mathrm{m}$ sieve. Retained material was preserved in buffered $10 \%$ formalin and stored in $70 \%$ EtOH. Sampling effort is expressed here both as numbers of individuals collected and, because mussel beds are 3dimensional features, as volume of mussels collected per sample. After washing, mussel sample volume (in liters) was determined by displacement of plasticbagged mussels immersed in seawater in a graduated container.

Sieved samples were sorted twice under a dissecting microscope, the second time after staining with Rose Bengal. Staining reduces contrast in the tissue and can make species identifications difficult, but it makes spotting the smallest individuals easier. All individuals were identified to the lowest taxonomic level possible (i.e. morphological species, except for copepods and nematodes) and counted. Quantitative measures of

Table 1. Locations of study sites and samples, southern East Pacific Rise. Dates given as mm/dd/yy

\begin{tabular}{|c|c|c|c|c|c|c|c|}
\hline Location & Site & Samples & Dive no. & Date & $\begin{array}{l}\text { Latitude } \\
\quad\left({ }^{\circ} \mathrm{S}\right)\end{array}$ & $\begin{array}{c}\text { Longitude } \\
\left({ }^{\circ} \mathrm{W}\right)\end{array}$ & $\begin{array}{l}\text { Depth } \\
\text { (m) }\end{array}$ \\
\hline \multirow[t]{3}{*}{ Animal Farm } & 1 & $\mathrm{~A}$ & 3343 & 2/2/99 & 1836.429 & 11323.995 & 2675 \\
\hline & 1 & B & 3349 & 2/8/99 & 1836.429 & 11323.995 & 2675 \\
\hline & 2 & $\mathrm{~A}-\mathrm{E}$ & 3349 & 2/8/99 & 1836.436 & 11323.992 & 2675 \\
\hline \multirow[t]{6}{*}{ Oasis } & 1 & $\mathrm{~A}$ & 3358 & 2/19/99 & 1725.395 & 11312.327 & 2582 \\
\hline & 2 & $\mathrm{~A}, \mathrm{~B}$ & 3358 & 2/19/99 & 1725.401 & 11312.323 & 2582 \\
\hline & 3 & $\mathrm{~A}, \mathrm{~B}$ & 3358 & 2/19/99 & 1725.394 & 11312.324 & 2582 \\
\hline & 4 & A & 3358 & 2/19/99 & 1725.367 & 11312.320 & 2582 \\
\hline & 5 & $\mathrm{~A}$ & 3358 & 2/19/99 & 1725.362 & 11312.326 & 2582 \\
\hline & 6 & A & 3358 & 2/19/99 & 1725.354 & 11312.323 & 2582 \\
\hline \multirow[t]{2}{*}{ Rehu Marka } & 1 & $\mathrm{~A}-\mathrm{C}$ & 3362 & 2/23/99 & 1724.948 & 11312.187 & 2581 \\
\hline & 2 & A-D & 3362 & 2/23/99 & 1724.930 & 11312.204 & 2581 \\
\hline
\end{tabular}




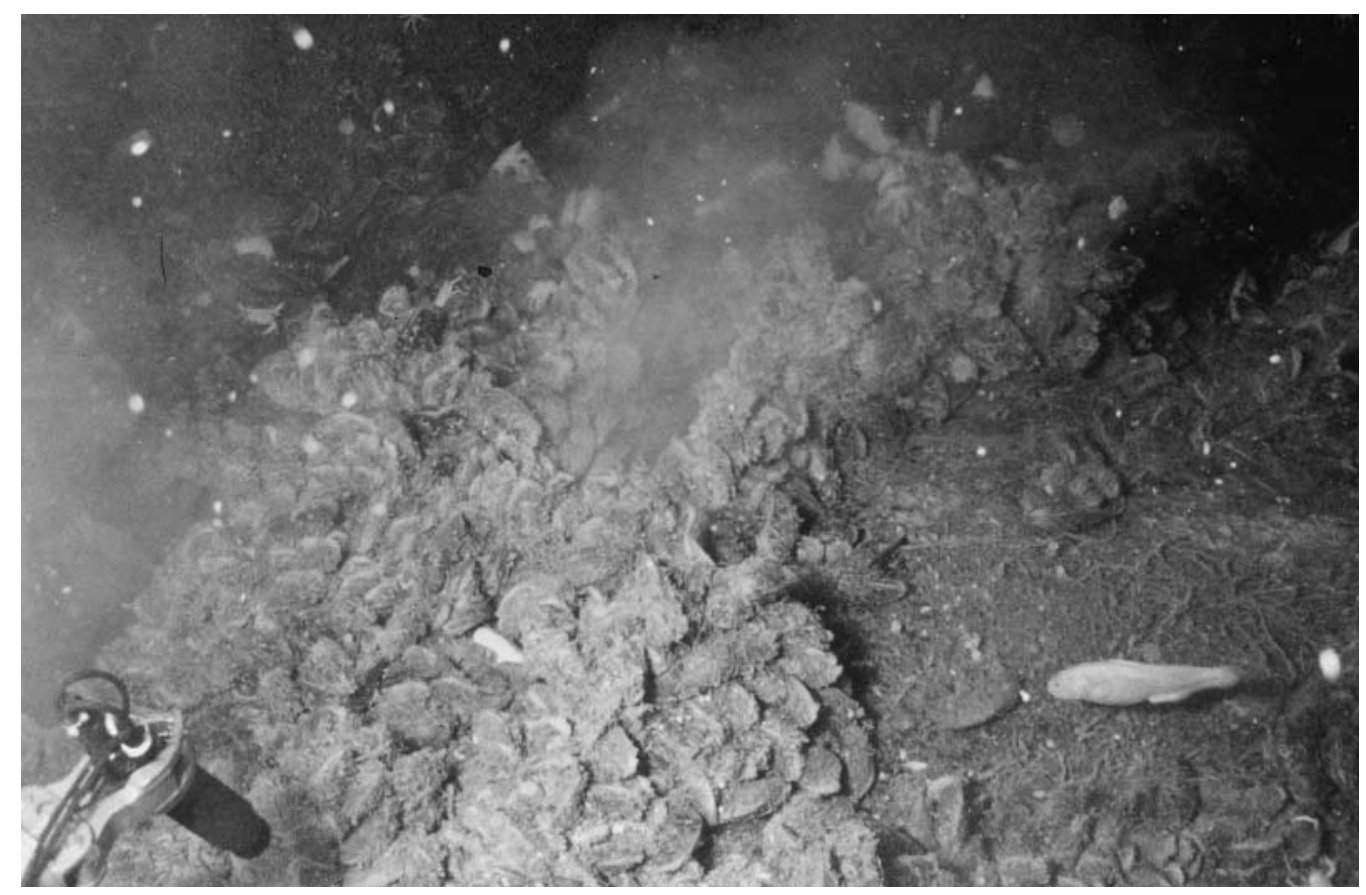

Fig. 2. Bathymodiolus thermophilus mussel bed at Oasis, southern East Pacific Rise. Manipulator (lower left) is holding a temperature probe. Milky clouds of bacteria can be seen to the left and in the center of the photograph

species abundance, expressed throughout the paper as individuals, represent numbers of individuals per liter mussel volume.

Taxa observed on video but not collected in the samples (e.g. the galatheid squat lobster Munidopsis subsquamosa and the bythograeid crab Bythograea thermydron) were not included in this analysis. Species commensal in mussels (i.e. the polynoid polychaete Branchipolynoe symmytilida) were also not included in diversity measures because they are not a part of the fauna that occupies the interstitial volume of the mussel bed. Mussels $<5 \mathrm{~mm}$ are of the same size as the rest of the mussel-associated fauna and were deemed to be part of the associated fauna rather than structural at this stage of their life history. They are thus included in the diversity measures.

Mussel size-frequency distributions were calculated using mussel lengths measured with digital calipers. Mussel tissues were dried to constant weight at $70^{\circ} \mathrm{C}$ for dry-weight measures.

Size-frequency distributions of abundant invertebrates from Oasis and Rehu Marka were made using an ocular micrometer. Dimensions measured were maximum length (limpets: Lepetodrilus elevatus, L. ovalis, Eulepetopsis vitrea), carapace length (leptostracan: Dahlella caldariensis), maximum body width (polychaete: Amphisamytha galapagensis), and disk diameter (ophiuroid: Ophiura nov. sp.). For several of these species (L. elevatus, E. vitrea, and A. galapagen- sis), all individuals from only a subset of samples from the Oasis and Rehu Marka sites were measured. The abundance of smallest size classes is used as an integral measure of settlement and post-settlement processes (predation, competition, etc.) and is referred to here simply as recruitment.

Species-effort curves, incidence (ICE)- and abundance (ACE)-based coverage estimators of species richness (ICE: Lee \& Chao 1994, ACE: Chao et al. 1993, Colwell \& Coddington 1994), and diversity indices were calculated for each vent field using EstimateS (Colwell unpubl. software, available at http://viceroy. eeb.uconn.edu/EstimateS; randomization operations = 50; rare cut-off $=10$ individuals for the area-based coverage estimate). ICE and ACE are non-parametric algorithms that rely on the number of species found in only 1 or 2 samples (uniques and duplicates, ICE) or the number of species represented by 1 or 2 individuals (singletons or doubletons, ACE) in the entire data set to make an estimate of true species richness.

Binary (species presence/absence) matrices were used to calculate Jaccard coefficients; species-abundance data (expressed as number of individuals $\mathrm{l}^{-1}$ sample volume) were compared using product-moment coefficients. Cluster analysis was performed using Clustan Graphics (Wishart 2000) using the unweighted pair group method and the arithmetic averages (UPGMA) algorithm. Analysis of covariance and $\chi^{2}$ tests were run using MiniTab software (Version 13.20, 2000). 


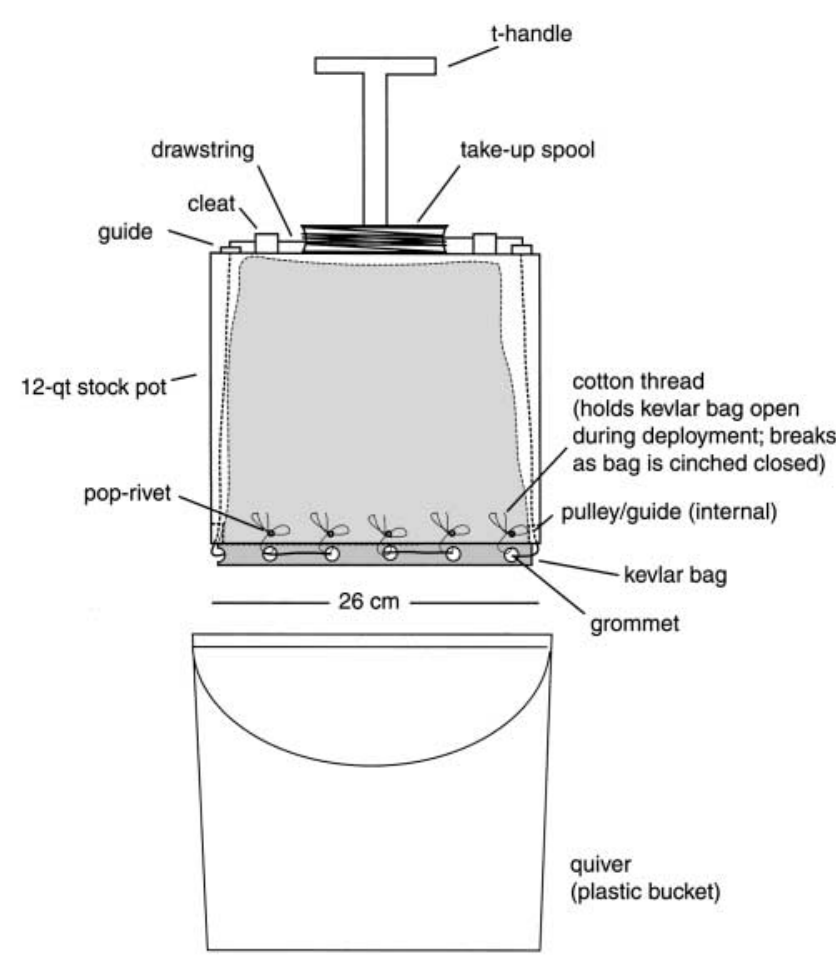

Fig. 3. Quantitative mussel 'pot' sampler. With the bottom of the bag held open by cotton threads and flush with the metal rim of the stock pot (12 qt $=11.35 \mathrm{l})$, the sampler is manipulated down over a clump of mussels. Once the bottom of the pot rests against basalt, the t-handle is rotated, causing the drawstring to be taken up onto the spool and cinching up the bag beneath the mussel clump. A stop bar (not illustrated) prevents the pot from spinning as the manipulator wrist is rotated. Once the sample is collected, the pot fits snugly into a quiver that is attached to the work basket of the submersible

Because copepods were not identified to species in the SEPR samples, the species data set from the Lucky Strike vent on the Mid-Atlantic Ridge (Van Dover \& Trask 2000) was modified to represent a similar level of taxonomic specificity (i.e. diversity from MAR vents is lower here than reported by Van Dover \& Trask [2000] through consolidation of 6 copepod species into a single 'copepod' taxon).

\section{RESULTS}

\section{Site descriptions}

Animal Farm is poorly age-constrained but, because of its geological characteristics, the field is thought to be located on a lava flow that is decades old (i.e. $>20$ yr: J. Sinton pers. comm.). The Oasis field is located on a lava flow that had 'young' characteristics in 1993; large areas of diffuse discharge without sessile animals and with a turbid, flocculent appearance
(Fouquet et al. 1994, Auzende et al. 1996). The Oasis field corresponds to the northern ' $\mathrm{L} 0$ ' region of the Embley et al. (1998) study, where, in 1995, 'Shinkai 6500' divers observed colonization of small, low-effusion-rate vents in what had been described as 'uncolonized areas of shimmering water' by 'Nautile' divers the previous year (Fouquet et al. 1994). From this, I infer that mussel beds at Oasis were approximately 6 yr old or less when sampled in 1999. The Rehu Marka lava flow, named by the 'Naudur' dive program (Geistdoerfer et al. 1995, Auzende et al.1996), was no more than 16 yr old at the time of my 1999 mussel sampling, based on observations of this lava flow during dives in 1984 (Renard et al. 1985, Fouquet et al. 1994). Given these observations, the relationship of lava flows at the 3 primary fields at the time of the 1999 sampling was Animal Farm ( 20 to 30 yr) > Rehu Marka ( 16 yr) > Oasis ( $\sim 6 \mathrm{yr})$. Note that the age of lava flows constrains only the maximum possible age of a mussel bed. Mussel beds do not necessarily become established in the same year of formation of the lava bed.

Major differences in flow regimes were observed among the 3 primary fields. Animal Farm was clearly in a waning stage of the hydrothermal cycle. No shimmering water was noted, nor was it possible to detect a temperature anomaly greater than $0.1^{\circ} \mathrm{C}$ above the ambient of $1.7^{\circ} \mathrm{C}$. Most $(\sim 75 \%)$ of the mussels at Animal Farm were dead, and those mussels that were alive were no longer attached by byssal threads to each other or the substratum. Thriving mussel beds (near $0 \%$ mortality) sustained by vigorous diffuse flows $\left(4.5^{\circ} \mathrm{C}\right.$ above ambient) were observed at Oasis. At Rehu Marka, live mussel beds with vigorous diffuse flow $8^{\circ} \mathrm{C}$ above ambient were interwoven through extensive beds of empty mussel valves.

Based on these observations of fluid flow and mussel mortality, the level of venting among primary fields at the time of the 1999 sampling was Animal Farm $<<<$ Rehu Marka < Oasis. This relationship is consistent with anticipated changes in a hydrothermal cycle with lava flow age, i.e. the most vigorous flow is at the youngest field.

The geological setting of all 3 fields was similar, with mussel beds occurring on low-relief $(<0.5 \mathrm{~m})$ lobate or sheet basalt lava. The beds themselves were closely associated with the folds between lobes or cracks within sheets of the lavas. Bed edges were abrupt, and appeared to be defined by the flow of and access to hydrothermal fluids rather than by biotic interactions.

\section{Mussel size-frequency distributions}

Mussel size-frequency distributions were determined for the 3 vent fields (Fig. 4). For mussels $>25 \mathrm{~mm}$ 


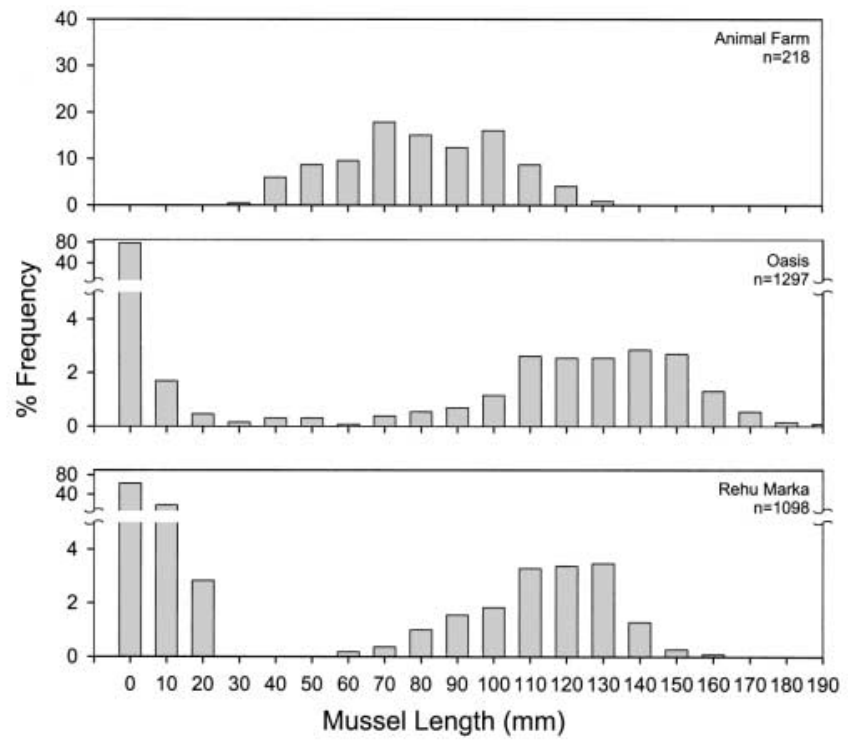

Fig. 4. Mussel size-frequency histograms of the 3 vent fields on the southern East Pacific Rise

length, distributions were significantly different for all pairwise comparisons between fields $\left(\chi^{2}, p<0.001\right)$. The hierarchy of maximum lengths was Oasis $>$ Rehu Marka > Animal Farm. Mussel post-larvae and small juveniles were extremely abundant at Oasis and Rehu Marka, accounting for more than $80 \%$ of the total mussels at each site (Fig. 4). Appropriate sampling for measuring within-field variation in size-frequency distributions was not undertaken, but visual and video records of sample sites provide evidence of fairly uniform mussel size-class distributions throughout each field.

If I assume that mussel growth rates were similar among vent fields, the age relationship from oldest to youngest field based on maximum mussel length is Oasis > Rehu Marka > Animal Farm. This would contradict direct observations and inferences made above regarding ages of fields. Applying ontogenetic growth curves developed for Galápagos Rift mussels based on mark-recapture experiments (Lutz et al. 1985), $190 \mathrm{~mm}$ mussels from Oasis were $>15$ yr old, which is an unrealistic age estimate for mussels collected at this location given the direct field observations of the age of the Oasis field ( $6 \mathrm{yr})$. These contradictions underscore the likelihood that mussel growth rates in fact vary considerably from field to field. There may be differential mortality as well. Larger mussels may be most susceptible to mortality when vent flow diminishes and chemoautotrophic symbiont contributions to host nutrition sinks to zero, due to the correspondingly greater metabolic demands of the larger host tissue biomass. This could account for the absence of large live mussels at Animal Farm.

\section{Mussel length and dry-weight relationships}

There was a significant ( $p<0.05)$, positive relationship between mussel length and tissue dry weight for Animal Farm and Oasis mussel populations, with much greater tissue biomass per mm shell length at Oasis than at Animal Farm (Fig. 5). Gill tissues of Animal Farm mussels were thin and transparent yellow in color; gill tissues of Oasis and Rehu Marka mussels were more 'normal', appearing engorged and opaque grey in color. No significant relationship between shell length and tissue dry weight was found in combined Rehu Marka subsamples from Sites 1 and 2, although the relationship was significant and positive for each site analyzed independently. There was no significant difference between the mussel dry-weight/shell length relationships of Oasis and Rehu Marka Site 1, but all other pairwise comparisons were significantly different (Fig. 5).

\section{Comparison of qualitative and quantitative samples}

In a comparison of quantitative and qualitative paired samples at Oasis Sites 2 and 3, the greatest dif-

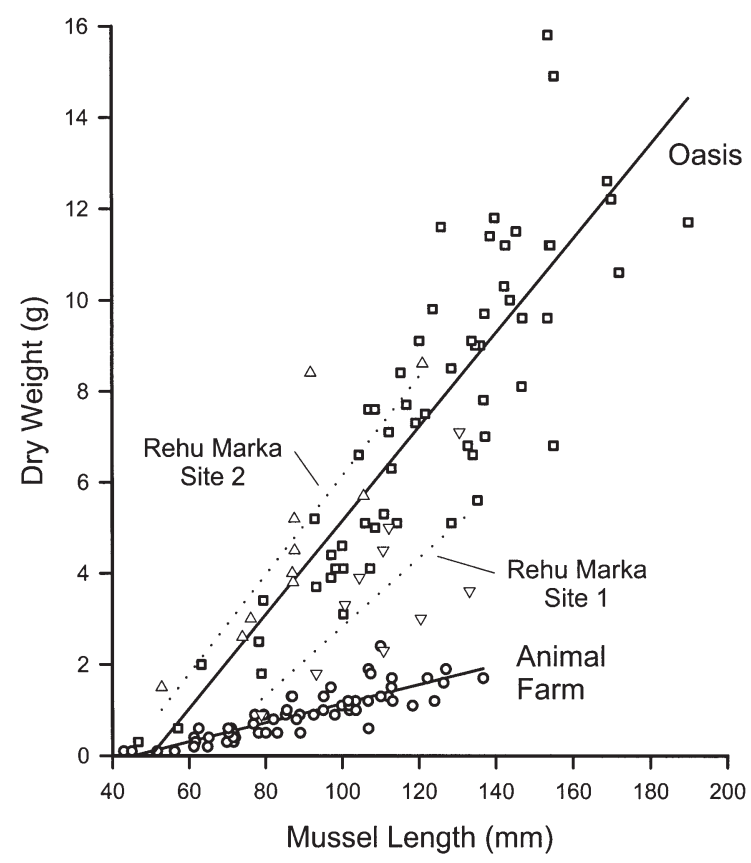

Fig. 5. Mussel shell-length versus body tissue dry weight from SEPR fields. R² values: Animal Farm (O): 0.74; Oasis ( $\square$ ): 0.74; Rehu Marka Site $1(\nabla)$ : 0.50; Rehu Marka Site $2(\Delta)$ : 0.72. ANCOVA results $\left({ }^{* * *} \mathrm{p}<0.001\right)$ : Oasis vs Animal Farm: $F_{1,117}$ $=134.10\left({ }^{* * *}\right)$; Oasis vs Rehu Marka Site $1: F_{1,67}=2.1(\mathrm{p}>$ 0.05); Oasis vs Rehu Marka Site 2: $F_{1,67}=19.54\left({ }^{* * *}\right)$; Rehu Marka Site 1 vs Rehu Marka Site 2: $F_{1,17}=21.51\left({ }^{* * *}\right)$; Animal Farm vs Rehu Marka Site 1: $F_{1,67}=220.7\left({ }^{* * *}\right)$; Animal Farm vs Rehu Marka Site 2: $F_{1,67}=91.09\left({ }^{* * *}\right)$ 
Table 2. Comparison of paired quantitative $\left(\mathrm{A}^{*}\right)$ and qualitative $(\mathrm{B})$ measures of abundance (individuals $\mathrm{l}^{-1}$ mussels) within the most abundant taxa at Oasis

\begin{tabular}{|c|c|c|c|c|c|c|c|}
\hline \multirow[t]{2}{*}{ Site 2} & \multicolumn{3}{|c|}{ Samples } & \multirow[t]{2}{*}{ Site 3} & \multicolumn{3}{|c|}{ Samples } \\
\hline & $\mathrm{A}^{*}$ & $\mathrm{~B}$ & $\mathrm{~A}^{*} / \mathrm{B}$ & & $\mathrm{A}^{*}$ & $\mathrm{~B}$ & $\mathrm{~A}^{*} / \mathrm{B}$ \\
\hline Ventiella sulfuris & 800 & 108 & 7 & Ventiella sulfuris & 570 & 31 & 19 \\
\hline Lepetodrilus elevatus & 114 & 99 & 1 & Lepetodrilus elevatus & 50 & 42 & 1 \\
\hline Bathymodiolus thermophilus (<5 mm) & 85 & 25 & 3 & Bathymodiolus thermophilus (<5 mm) & 37 & 25 & 1 \\
\hline Copepods & 80 & 9 & 9 & Amphismytha galapagensis & 30 & 47 & 1 \\
\hline Ophryotrocha akessoni & 64 & 23 & 3 & Copepods & 20 & 8 & 2 \\
\hline Amphismytha galapagensis & 64 & 29 & 2 & Lepetodrilus ovalis & 17 & 23 & 1 \\
\hline Syrrhoe sp. & 33 & 2 & 15 & Eulepetopsis vitrea & 11 & 5 & 2 \\
\hline Dahlella caldariensis & 31 & 24 & 1 & Ophryotrocha akessoni & 10 & 10 & 1 \\
\hline Lepetodrilus ovalis & 25 & 18 & 1 & Nematodes & 6 & 8 & 1 \\
\hline Eulepetopsis vitrea & 16 & 9 & 2 & Gorgoleptis spiralis & 4 & 3 & 1 \\
\hline
\end{tabular}

ference was found in the abundance of highly motile amphipods (Ventiella sulfuris, Syrrhoe sp.) and copepods, with the quantitative samples capturing anywhere from 7 to 19 times more individuals (Table 2). Abundances of sedentary organisms (gastropods, polychaetes, nematodes, leptostracans) were more consistent in quantitative and qualitative samples, averaging about 1.5 times higher in quantitative samples.

\section{Species composition, abundance, species-effort curves, and diversity indices}

Species lists and abundances for each sample within a field are provided in Tables 3 to 5. Randomized species-effort curves, whereby cumulative number of species is plotted against cumulative sample volume in liters or cumulative numbers of individuals, show that species accumulation patterns for Oasis and Rehu Marka mussel beds were similar (Fig. 6). Incremental sampling efforts beyond that undertaken for the southern East Pacific Rise sites would yield little benefit in species accumulation, regardless of site (Fig. 6A). Fig. 6 also includes data from comparable sampling efforts at the Lucky Strike hydrothermal field on the Mid-Atlantic Ridge and from June sampling at an intertidal site on the south-central Alaskan coast (Van Dover \& Trask 2000). Species accumulated much more slowly with increasing sample volume at Lucky Strike than at Oasis or Rehu Marka and they accumulated most quickly at the intertidal site. The patterns of species accumulation with increasing numbers of individuals sampled were similar for Animal Farm, Oasis, Rehu Marka, and the intertidal sites (Fig. 6B).

An ICE was used to estimate the true species richness for each location (Fig. 7). The hierarchy of species richness for invertebrates associated mussel beds using ICE was intertidal (77 species) > Oasis (68 spe- cies) > Rehu Marka (53 species) > Animal Farm (45 species) > Lucky Strike (28 species). At Rehu Marka, an ACE was calculated based on the 5 quantitative samples. The ACE estimate of true species richness at Rehu Marka was 52, i.e. 1 less than that estimated by ICE.

Species richness by itself provides no descriptive measure of the distribution of individuals within species. As at intertidal mussel beds, the associated fauna of vent mussel beds was dominated by a small number of extremely abundant species (Fig. 8). The most abundant species in vent mussel beds accounted for at least 25 to $35 \%$ of the total number of individuals, and sometimes represented as much as $70 \%$ of the total abundance. This contrasts with the situation typically found in non-vent deep-sea environments, where individuals are more evenly distributed among species (e.g. Grassle et al. 1985).

Diversity indices are also useful in making comparisons of community structure. Because measures of species richness do not take into account relative abundances, several diversity indices (Fisher's $\alpha$, Simpson's index, Shannon index) were calculated (Table 6). To test the effect of quantitative versus qualitative sampling, indices for Rehu Marka samples were calculated using all samples, quantitative samples only, and qualitative samples only (Table 6). There was little difference in the index values, regardless of the method of calculation, suggesting that qualitative samples provided reasonable estimates of the diversity indices. Diversity measures at Oasis, Rehu Marka, and the intertidal site were similar, but Animal Farm stood out as distinctive among the SEPR sites, with a relatively high value for Simpson's index (8.52 vs 5.48 to 6.2 for other SEPR sites). Diversity indices for the mussel bed community at Lucky Strike on the Mid-Atlantic Ridge were the most deviant, being uniformly relatively low compared to those of SEPR vent or intertidal mussel beds. 


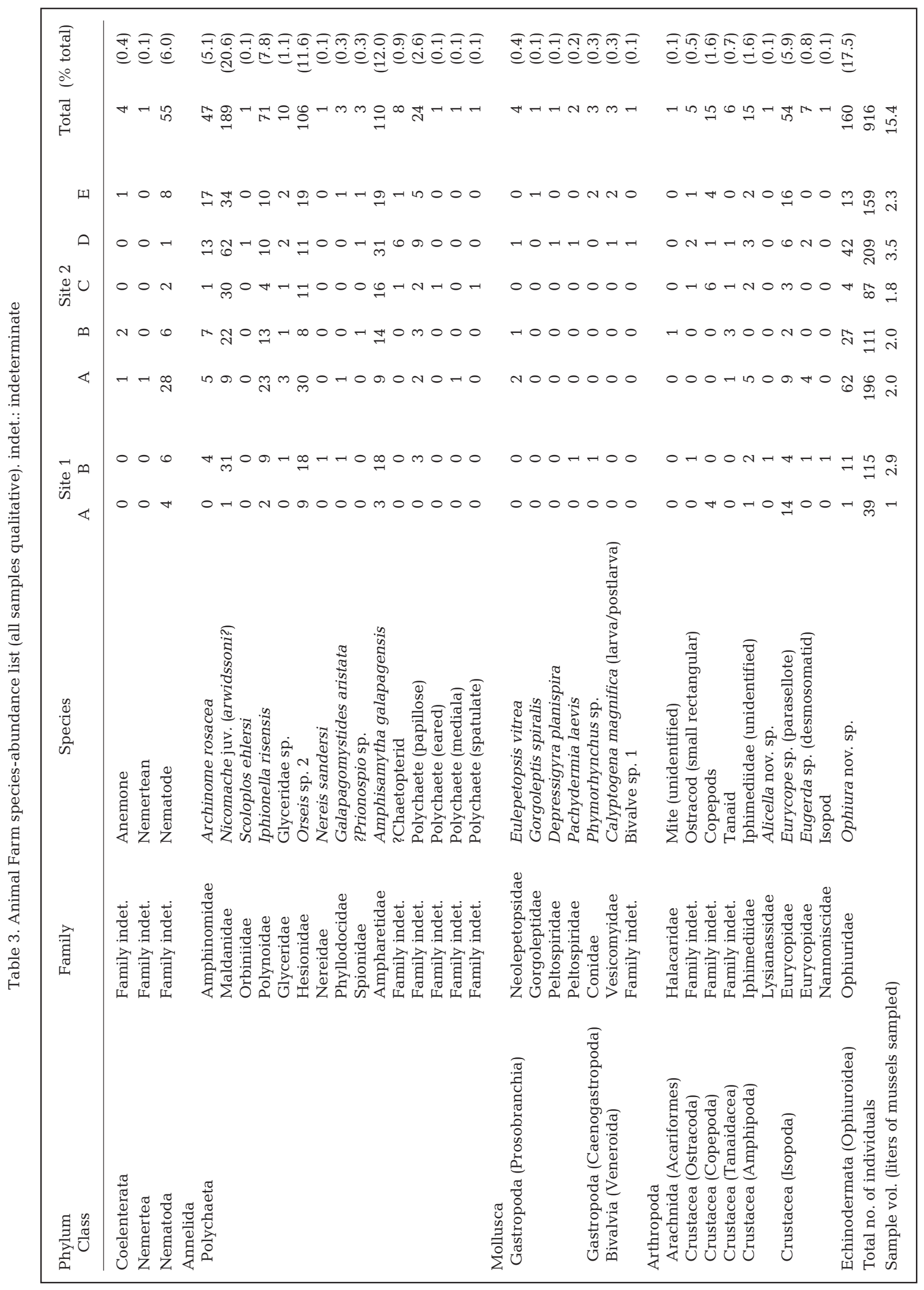




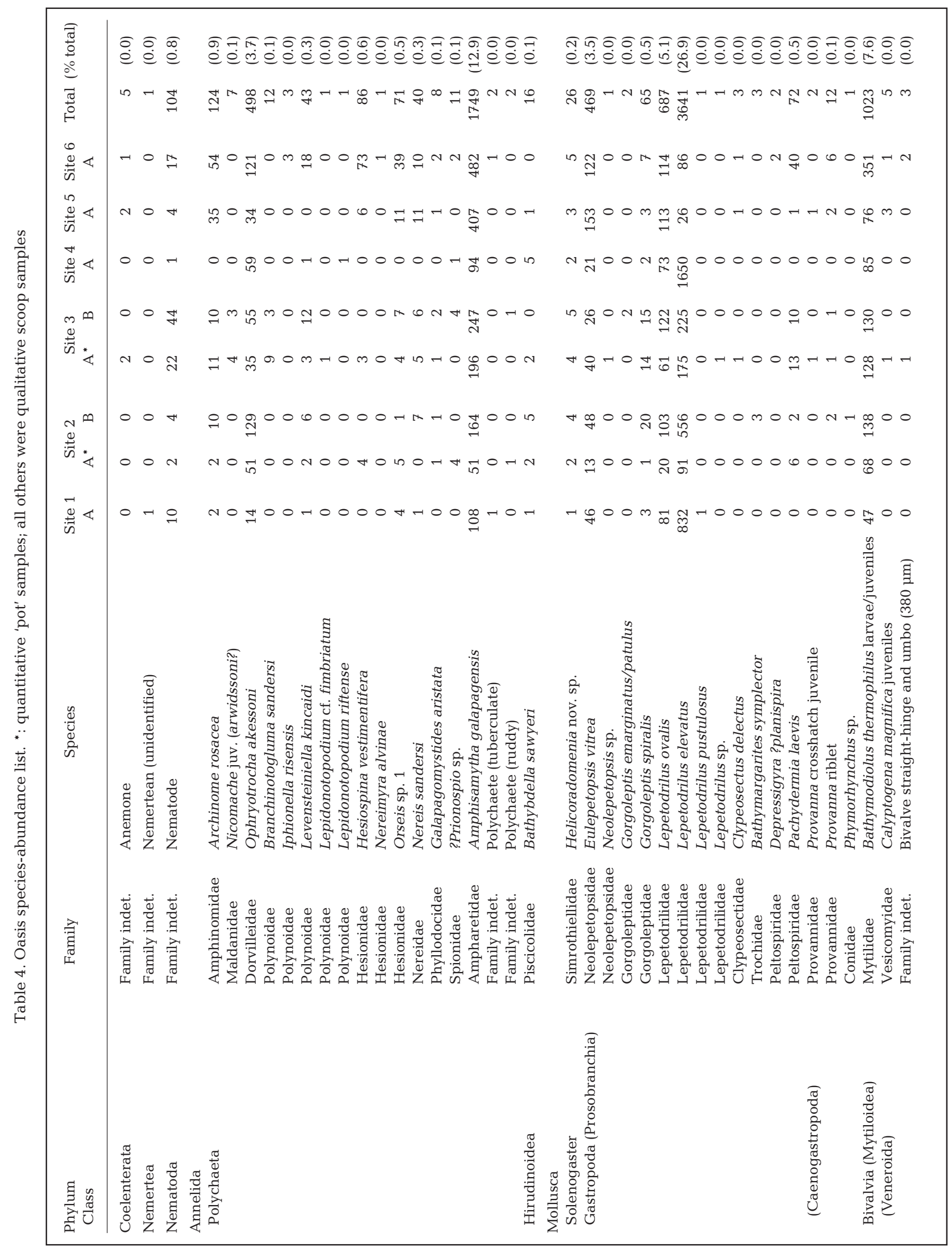



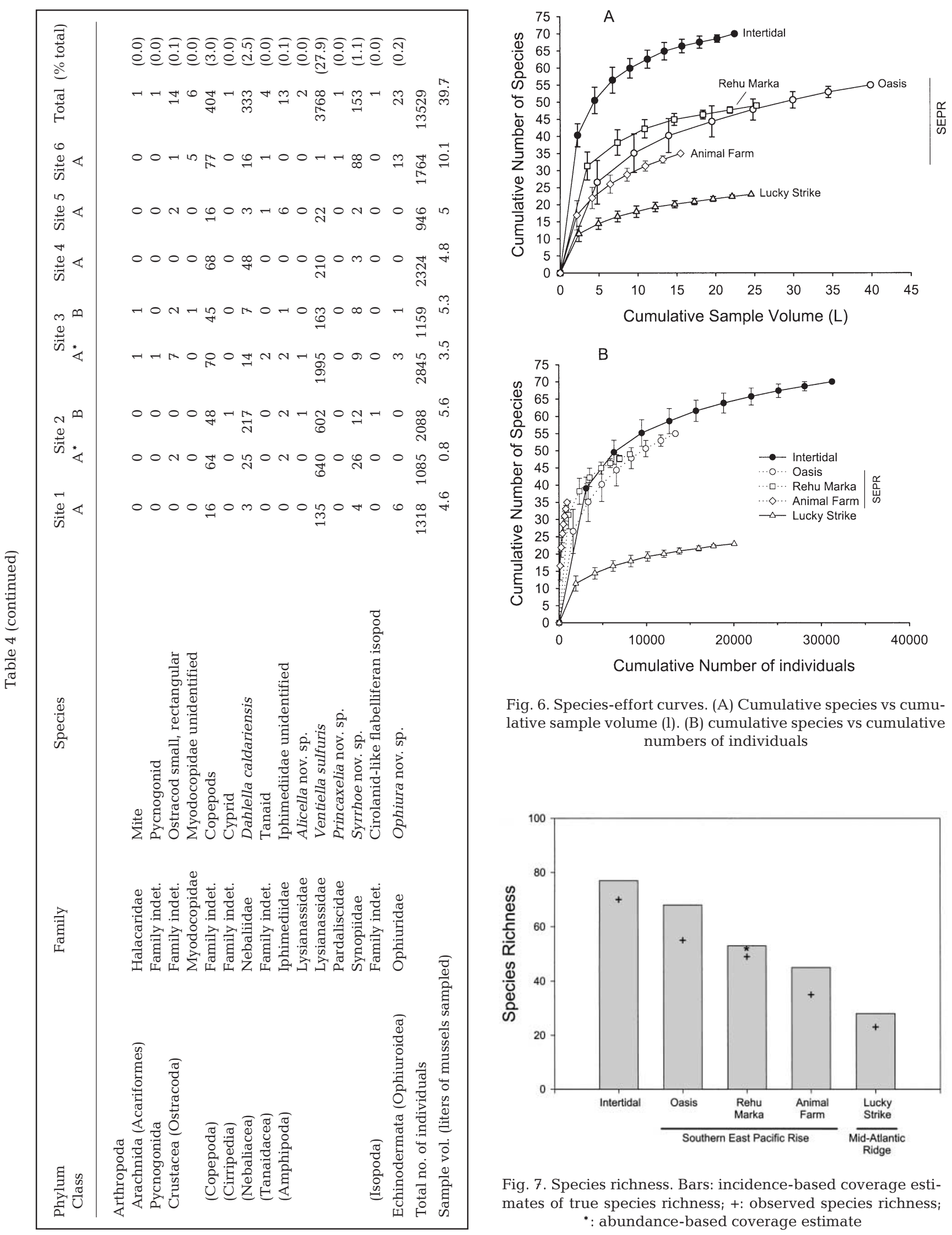

Fig. 6. Species-effort curves. (A) Cumulative species vs cumulative sample volume (l). (B) cumulative species vs cumulative numbers of individuals

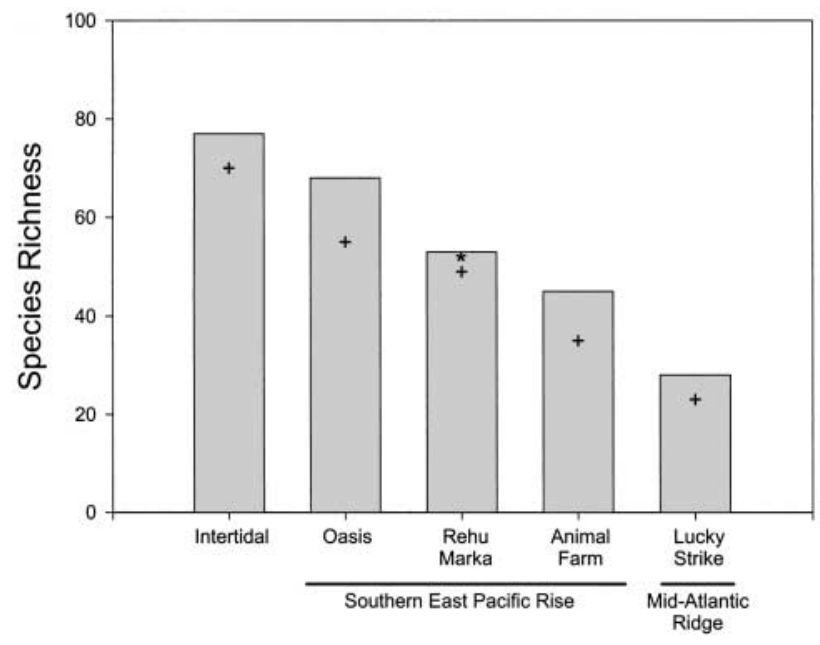

Fig. 7. Species richness. Bars: incidence-based coverage estimates of true species richness; +: observed species richness; ${ }^{*}$ : abundance-based coverage estimate 


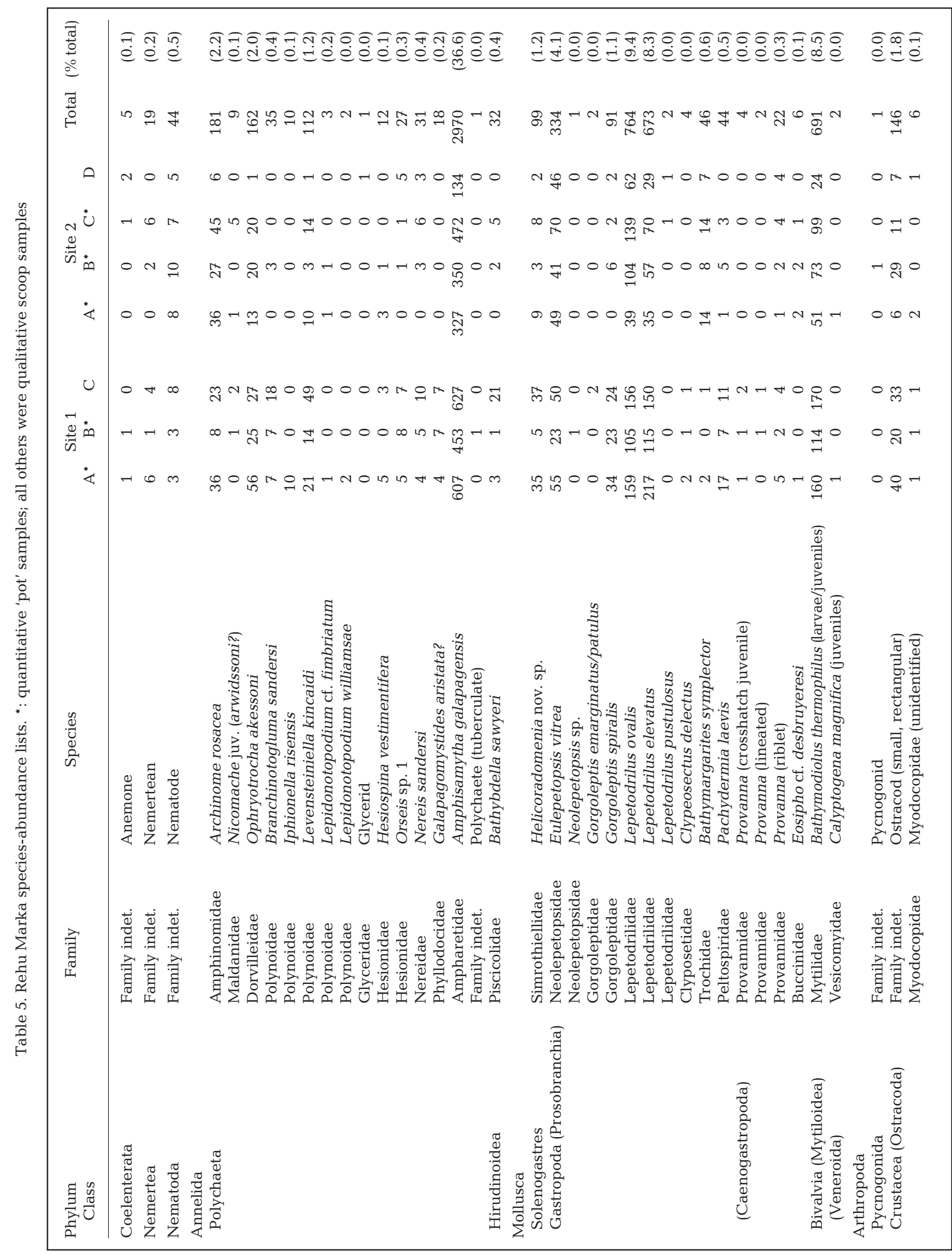




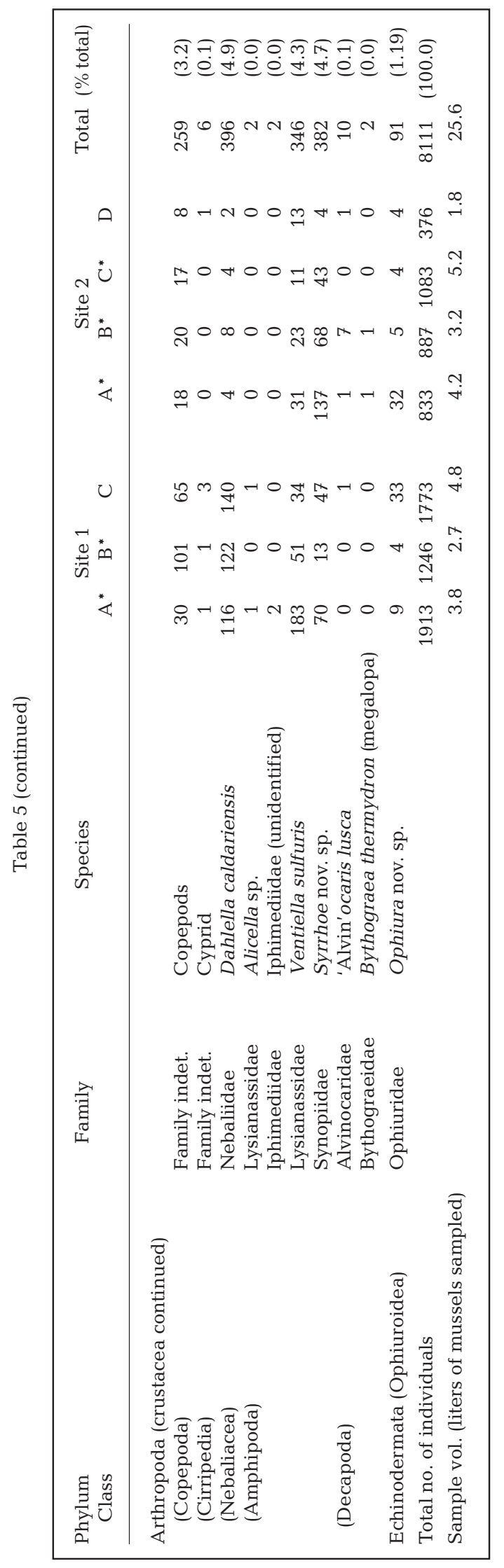

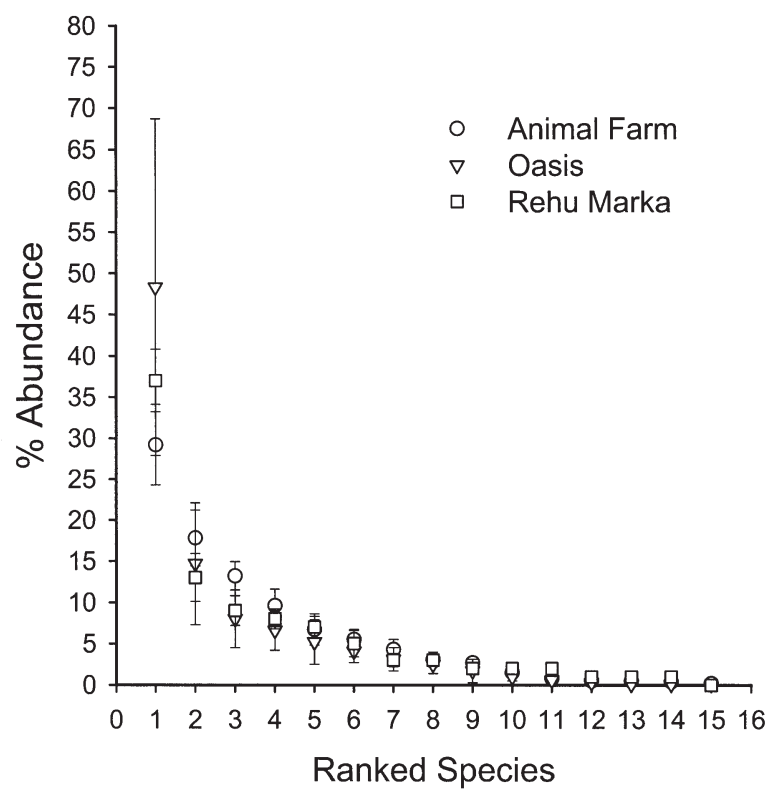

Fig. 8. Ranked species versus percentage abundance (mean \pm SD) for southern East Pacific Rise mussel bed faunas, calculated from all samples (quantitative 'pot' and qualitative 'scoop') at each site

Of the 3 SEPR mussel beds, Animal Farm supported the lowest biomass of associated organisms. This is reflected in the low total number of individuals in qualitative samples, normalized to sample volume $(59 \pm 20$ $[95 \% \mathrm{CI}]$ individuals $\mathrm{l}^{-1}$ ). The species list at Animal Farm is notable in that a number of typical non-vent deep-sea organisms had invaded the mussel bed (e.g. tanaid and isopod crustaceans), and several undescribed polychaete species found there are so far only known from this site. Populations of associated organisms at the Oasis $\left(487 \pm 342[95 \% \mathrm{CI}]\right.$ individuals $\left.\mathrm{l}^{-1}\right)$ and Rehu Marka (320 \pm 128 [95\% CI] individuals $\mathrm{l}^{-1}$ ) mussel beds were 5 to 8 times greater than those at Animal Farm, and not significantly different from each other (Mann-Whitney $U$-test; $\mathrm{p}=0.332$ ).

For comparison of species composition among samples and fields, data were arranged in a binary (presence/absence) matrix. Results of the Jaccard (UPGMA) cluster analysis method (Fig. 9A) emphasize: (1) the unique nature of the Animal Farm fauna compared to Oasis and Rehu Marka; (2) the overlap in species composition between Oasis and Rehu Marka fields; (3) the close clustering of replicate quantitative samples from the same sites within a vent field (i.e. Rehu Marka Sites 1 and 2); (4) within-field heterogeneity, as indicated for example by the difference between Rehu Marka Sites 1 and 2. The distinctiveness of the Animal Farm fauna is also apparent in the product-moment (UPGMA) cluster analysis which uses species-abundance data normalized to sample volume (Fig. 9B). While most of 
the Oasis and Rehu Marka sites cluster fairly tightly in the Jaccard analysis, Oasis Site 4A is nearly as different from the other Oasis and Rehu Marka samples as it is from the Animal Farm samples. The Oasis 4A site is distinctive in the very low number of species (17) recovered from it. When abundances are taken into account, the Oasis and Rehu Marka mussel bed faunas cluster much more strongly by vent field than when species presence/absence alone is compared.

Distribution of species and abundance within major groups (polychaetes, mollusks, crustaceans, other) compared among fields (Table 7) provides an overview of how the assemblages identified in the cluster analysis (Fig. 9) differ taxonomically. Animal Farm was dominated by polychaetes, both in numbers of species (43\%) and abundance (63\%). Oasis and Rehu Marka had identical distributions of species within major groups, but the relative abundance of individuals within polychaetes and mollusks was reciprocal. At Lucky Strike on the Mid-Atlantic Ridge, mollusks were the most speciose group, but crustaceans were overwhelming dominant in relative abundance $(88 \%)$. Although not quantitatively measured, the total biomass of invertebrates associated with mussel beds at Lucky Strike was much lower than that at Oasis and Rehu Marka on the East Pacific Rise. Animal Farm also had extremely low biomass.

\section{Quantitative analysis of between- and within-field heterogeneity}

Quantitative samples permit measurement of differences in the abundances of mussel-bed faunas between hydrothermal fields: 2 quantitative samples were collected from Oasis mussel beds and 5 from Rehu Marka. The average total abundance of individuals $\mathrm{l}^{-1}$ of mussel volume was significantly different between sites (student's $t$-test, $\mathrm{p}=0.01$ ). Abundances of individuals were more than 3 times greater at Oasis $\left(\bar{x}=1084\right.$ individuals $\left.\mathrm{l}^{-1}\right)$ than at Rehu Marka $(\bar{x}=331$ $\pm 180[95 \% \mathrm{CI}]$ individuals $\mathrm{l}^{-1}$ ). Of the top $10 \mathrm{most}$ abundant mussel bed taxa within quantitative samples collected at Oasis, 9 were shared between fields
Table 6. Diversity indices

\begin{tabular}{|lccc|}
\hline & Fisher's $\alpha$ & Simpson $(\lambda)$ & Shannon $\left(H^{\prime}\right)$ \\
\hline $\begin{array}{l}\text { Southern East Pacific Rise } \\
\text { Animal Farm }\end{array}$ & 7.21 & 8.52 & \\
$\quad$ Oasis & 7.33 & 5.48 & 2.47 \\
$\quad$ Rehu Marka & & & \\
$\quad$ All replicates $(\mathrm{n}=7)$ & 6.94 & 5.95 & 2.42 \\
$\quad$ Quantitative replicates $(\mathrm{n}=5)$ & 6.96 & 5.83 & 2.39 \\
$\quad$ Qualitative replicates $(\mathrm{n}=2)$ & 6.77 & 6.2 & 2.45 \\
$\begin{array}{l}\text { Mid-Atlantic Ridge } \\
\text { Lucky Strike }\end{array}$ & 2.57 & 3.5 & 1.47 \\
$\begin{array}{l}\text { Intertidal } \\
\text { Alaska (June) }\end{array}$ & 8.53 & 5.04 & 2.13 \\
\end{tabular}

Polychaetes 43

Crustacean

Percentage of abundance

Polychaetes

Crustaceans

Other

4

63

12

24
Percentage of species major taxonomic groups at SEPR and MAR vent fields

\section{Southern East Pacific Rise Mid-Atlantic Ridge Animal Farm Oasis Rehu Marka Lucky Strike}

$31 \quad 31 \quad 32$

$\begin{array}{llll}20 & 34 & 35 & 39\end{array}$

22

39

22

63
1
12
12

22
13

13

$\begin{array}{rr}20 & 44 \\ 44 & 20 \\ 35 & 34 \\ 1 & 2\end{array}$

17

2
7

88

7
7
2
7
88

(Fig. 10). At Rehu Marka, the polychaete Archinome rosacea replaces Ophryotrocha akessoni (also a polychaete). Apart from total abundance, the most conspicuous difference between these 2 vent fields was that at Oasis, where the overwhelming numerical dominant was the amphipod Ventiella sulfuris, while at Rehu Marka, the polychaete Amphisamytha galapagensis always outnumbered all other taxa (Fig. 10).

Quantitative samples from Rehu Marka can also be used to examine within-field heterogeneity. The total abundance of individuals $\mathrm{l}^{-1}$ (Fig. 10) was significantly higher at Site $1\left(\bar{x}=485\right.$ individuals $\left.1^{-1} ; \mathrm{n}=2\right)$ than at Site $2\left(\bar{x}=228 \pm 104[95 \% \mathrm{CI}]\right.$ individuals $\mathrm{l}^{-1} ; \mathrm{n}=3$; t-test, $\mathrm{p}<0.01)$. Amphisamytha galapagensis, Lepetodrilus elevatus, L. ovalis, and Bathymodiolus thermophilus (postlarvae/juveniles) were always among the top 5 most abundant species in quantitative samples from either site. Abundance data rather than species composition most readily distinguishes the 2 sites within Rehu Marka. 


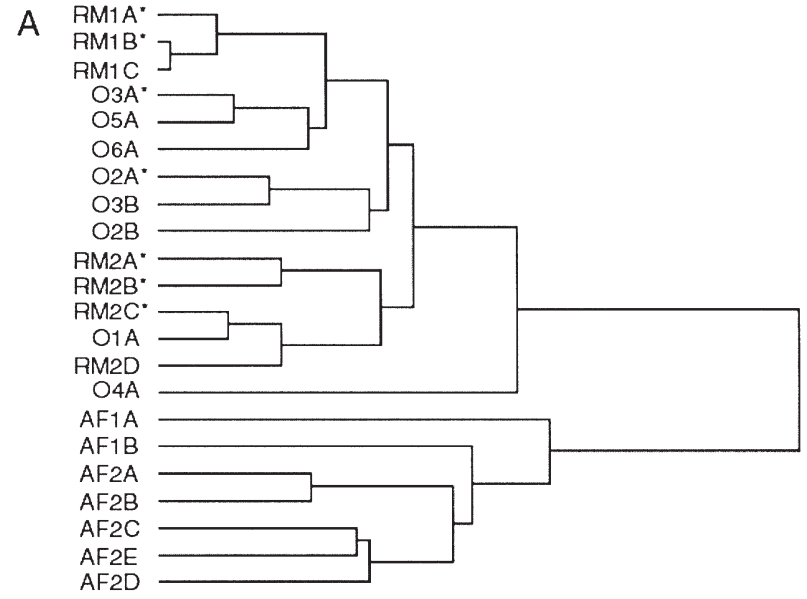

B RM1A*

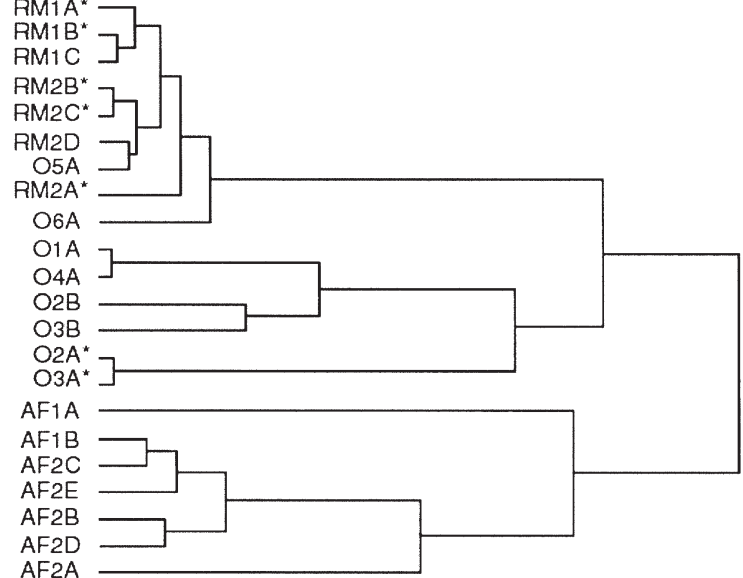

Fig. 9. Cluster analysis of Southern East Pacific Rise mussel bed fauna. (A) Species presence/absence comparisons (Jaccard coefficients); (B) Species and species abundance comparisons (product-moment coefficients). AF: Animal Farm; O: Oasis; RM: Rehu Marka. Site and sample designations (1-3; A-E) match those in Tables 1 to 5. Asterisks mark quantitative 'pot' samples, where collection of every species and individual within a mussel clump was assured; other samples are qualitative 'scoop' samples

\section{Recruitment and size-frequency distributions of selected taxa}

There was no evidence of substantial recent recruitment of any species at Animal Farm, with the exception of the ophiuroid (Ophiura nov. sp.), which was both relatively abundant and made up of a large percentage of juveniles ( $60 \%$ with test diameter $<1 \mathrm{~mm})$.

To document field-specific differences in apparent recruitment levels at Oasis and Rehu Marka, size-frequency distributions of selected, abundant taxa (Eulepetopsis vitrea, Ophiura nov. sp., Lepetodrilus elevatus, L. ovalis, Dahlella caldariensis and Amphi-

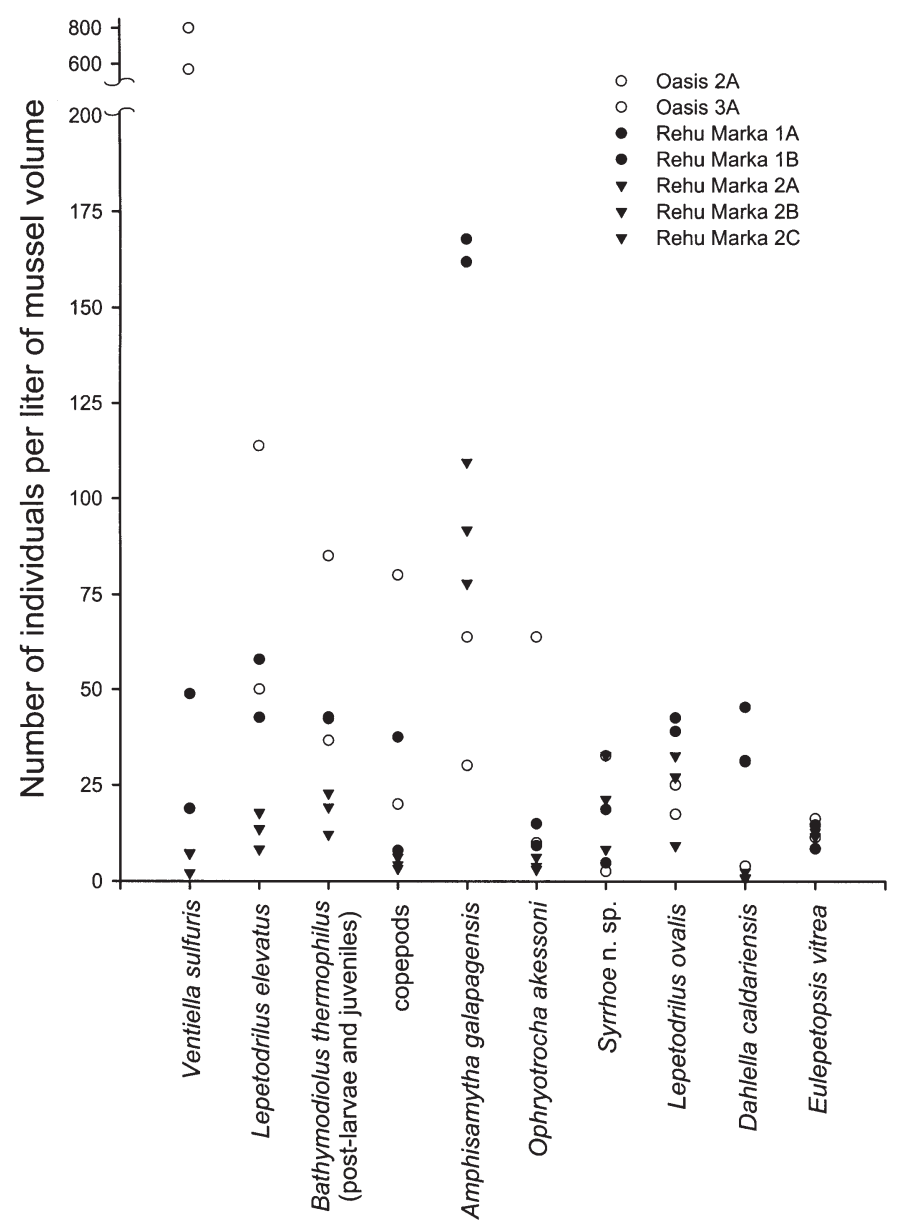

Fig. 10. Comparisons of species abundance (number of individuals $\mathrm{l}^{-1}$ mussels sampled) in quantitative 'pot' samples for the top 10 dominant species at Oasis

samytha galapagensis) were calculated (Fig. 11). Bimodal distributions were observed in all species. New recruits (smallest size-classes) dominated sizefrequency distributions of the limpet $L$. elevatus and the leptostracan D. caldariensis at both fields. In all cases, the percent-frequencies of the smallest size classes were largest at Oasis. The Oasis field also supported higher frequencies of larger size classes. $\chi^{2}$ tests indicate that the difference between vent fields of larger size-class distributions for each species in Fig. 11 was significant ( $p<0.001$ ), with the exception of Ophiura nov. sp., for which sample sizes were too small to make meaningful comparisons. Based on sizefrequency data from quantitative samples at Oasis (Samples 2A, 3A) and Rehu Marka (Samples 1A, 1B), the numbers of new recruits of $L$. elevatus $\mathrm{l}^{-1}$ (i.e. density of the smallest size class) were nearly twice $(1.7 \times)$ as high at Oasis as at Rehu Marka (Table 8). The abundances of mussel post-larvae were also tabulated by 
sample and, based on all the quantitative samples, the numbers per liter were more than twice as great at Oasis as at Rehu Marka (Table 8). The recruitment levels of Eulepetopsis vitrea, L. ovalis, and D. caldariensis were comparable between Oasis and Rehu Marka fields. These comparisons emphasize that recruitment to both fields was ongoing at the time of sampling and that there were field- and species-specific differences in apparent recruitment levels.

\section{Relationship between total abundance and species richness and productivity}

Direct measures of productivity at the southern East Pacific Rise vent fields were outside the scope of the sampling program. Mussel condition was a patent indicator of productivity, with mussels from the waning site (Animal Farm) being far more watery than those from the active vent sites (Oasis and Rehu Marka). Using the slopes of the mussel tissue dry-weight versus shell-
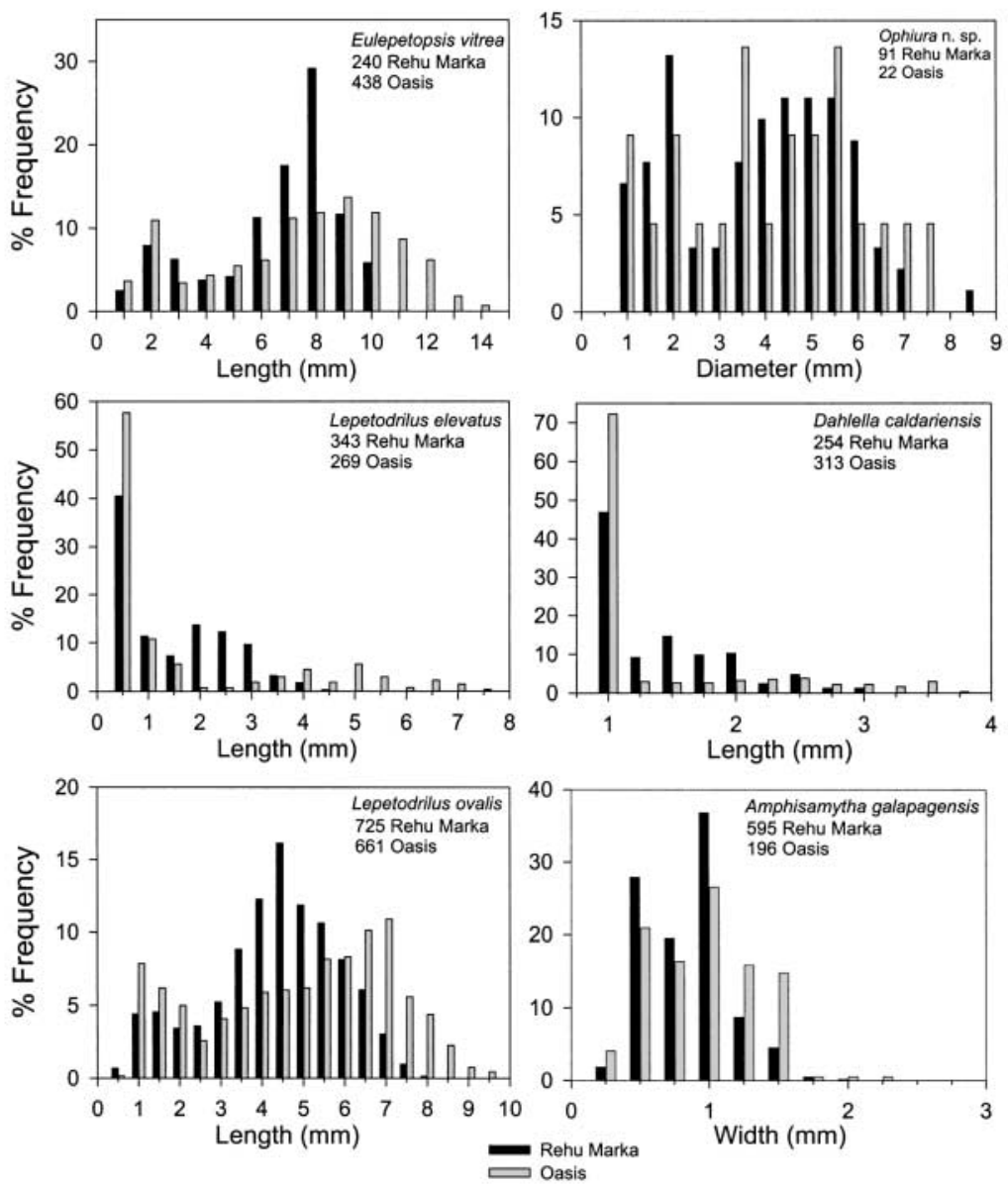

Fig. 11. Size-frequency distributions of selected taxa from Oasis and Rehu Marka. Values given next to field names are total numbers measured length relationships for Animal Farm, Oasis, and Rehu Marka Sites 1 and 2 (Fig. 5) as an index of productivity, there is a significant positive correlation between this measure of productivity and abundance (Fig. 12A; Pearson product-moment, $\mathrm{p}<0.05$ ). If only quantitative data from Oasis and Rehu Marka Sites 1 and 2 are used, however, the correlation is not significant. There is a trend toward increasing species richness with productivity (Fig. 12B), but again the correlation is not significant (Pearson product-moment, $\mathrm{p}>0.05$ ).

\section{DISCUSSION}

\section{Community structure and composition of Southern East Pacific Rise mussel beds}

This study expands the range of dozens of vent species previously known only from hydrothermal vents on ridge systems north of the equator, and it confirms the suggestion by Geistoderfer et al. (1995) that SEPR vents are similar to that of northern East Pacific Rise communities. Geistdoerfer et al. (1995) based their conclusion on the nature of the megafauna, which includes tubeworms (Riftia pachyptila), clams (Calyptogena magnifica), and mussels (Bathymodiolus thermophilus). Recent intense sampling and analysis of invertebrates associated with mussel beds at the $9^{\circ} 50^{\prime} \mathrm{N}$ vent site (Van Dover unpubl. data) suggest that the $9^{\circ} 50^{\prime} \mathrm{N}$ fauna is largely a subset of the southern East Pacific Rise fauna described here. Of the taxa listed in this report, only the buccinid Eosipho cf. desbruyeresi, represented by a single individual at Rehu Marka, belongs to a genus so far known only from western Pacific back-arc basin hydrothermal vents. Only a small number of species collected in this study are undescribed. The large proportion of shared species between southern and northern East Pacific Rise vent faunas suggests that fields are spaced closely enough to allow larval and/or adult dispersal from one field to another in a stepping-stone manner, and that there are no substantial hydrographic barriers to dispersal for most species along more than $3000 \mathrm{~km}$ of ridge axis. The East Pacific Rise thus represents a single hydrothermal biogeographic province over at least 31 degrees of latitude $\left(13^{\circ} \mathrm{N}\right.$ to $\left.18^{\circ} \mathrm{S}\right)$. This contrasts with, for example, the character of the 
Table 8. Abundance (nos. $\mathrm{l}^{-1}$ )of smallest size classes at Oasis and Rehu Marka in quantitative samples. Smallest size-class abundances of Lepetodrilus elevatus for Rehu Marka were calculated from only 2 of 3 quantitative samples (Sites 1A and 2C); smallest size-class abundance of Amphisamytha galapagensis for Oasis was calculated from Site 3A and for Rehu Marka from Site 1A. Abundances of the remaining species were calculated from pooled data of all quantitative samples

\begin{tabular}{|c|c|c|}
\hline \multirow{2}{*}{ Species } & \multicolumn{2}{|c|}{ Abundance } \\
\hline & Oasis & Rehu Marka \\
\hline Lepetodrilus elevatus $^{\mathrm{a}}$ & 36 & 21 \\
\hline Bathymodiolus thermophilus larvae $\mathrm{a}^{\mathrm{a}}$ & 18 & 8 \\
\hline Dahlella caldariensis ${ }^{\mathrm{a}}$ & 5 & 6 \\
\hline Lepetodrilus ovalis $^{\mathrm{a}}$ & 2 & 1.8 \\
\hline Amphisamytha galapagensis ${ }^{\mathrm{b}}$ & 2 & 2 \\
\hline Eulepetopsis vitrea ${ }^{\mathrm{a}}$ & $<1$ & $<1$ \\
\hline Ophiura nov. sp. ${ }^{\mathrm{c}}$ & $<1$ & $<1$ \\
\hline $\begin{array}{l}\mathrm{a}^{\mathrm{a}}<1 \mathrm{~mm} \text { length } \\
\mathrm{b}^{\mathrm{b}}<0.5 \mathrm{~mm} \text { maximum width } \\
{ }^{c}<1 \mathrm{~mm} \text { diameter }\end{array}$ & & \\
\hline
\end{tabular}

intertidal east coast of North America, where both climate and currents drive species replacements and generate multiple biogeographic provinces (Acadian, Virginian, Carolinian, West Indian, Louisianian) over 20 degrees of latitude $\left(45^{\circ} \mathrm{N}\right.$ [Bay of Fundy] to $25^{\circ} \mathrm{N}$ [Florida Keys and the Gulf Coast]).

In contrast to shallow-water mussel beds, none of the taxa associated with southern East Pacific Rise mussel beds are encrusting or otherwise cemented to mussel shells, and none are colonial. The trophic characteristics of most taxa are unknown. The mussels themselves are capable of suspension-feeding in addition to having a nutritional reliance on gill endosymbionts (Page et al. 1991). Many of the most abundant taxa associated with mussel beds (e.g. the polychaete Amphisamytha galapagensis and the amphipods) are presumed to be bacteriovores and grazers on detritus. Some of the limpets may eventually be shown to host chemoautotrophic endosymbionts, but at present they are also presumed to be bacteriovores and grazers. Copepods are predominantly siphonostomes, with piercing mouthparts, and are thus thought to be ectoparasitic, although specific hosts are not known. At least 1 of the polychaetes (Archinome rosacea) is omnivorous, feeding on detritus and captured prey (small crustaceans, limpets: Ward \& Van Dover unpubl. data). The dietary characteristics of most vent invertebrates at this point must be inferred from the diets of shallow-water analogs.

Community structure and species composition of the invertebrate fauna within mussel beds of the Oasis and Rehu Marka vent fields were similar, despite their occurrence on 2 distinct lava flows of different ages and their geographical separation of nearly $1 \mathrm{~km}$.
Oasis had a greater estimated true species richness than Rehu Marka (68 versus 53), but diversity measures were similar (Table 6).

The Oasis and Rehu Marka mussel beds shared $>75 \%$ of their total species lists (Tables 3 to 5) and shared $100 \%$ of the most common (i.e. $\mathrm{n}>15$ individuals per field) taxa. Oasis and Rehu Marka were distinguishable, however, by the relative abundances of the most common species. The amphipod Ventiella sulfuris was numerically dominant at Oasis, while the polychaete Amphisamytha galapagensis dominated at Rehu Marka mussel beds (Fig. 10). Both species are likely to be grazers on microbial production, so that the inverse relationship may represent a competitive displacement, although predation or recruitment/migration factors cannot be ruled out. This interpretation is compromised by the tendency of $V$. sulfuris to swarm above mussel beds in a patchy manner (Van Dover pers. obs.). It is unlikely that the highly mobile amphipods display long-term fidelity to a given patch of mussels; thus their dominance at a site may be ephemeral on a scale of hours. The limpets Lepetodrilus elevatus and L. ovalis might a priori be thought to have the greatest potential for competitive interactions, given their similar appearance and presumed mode of nutrition. There was, however, no significant
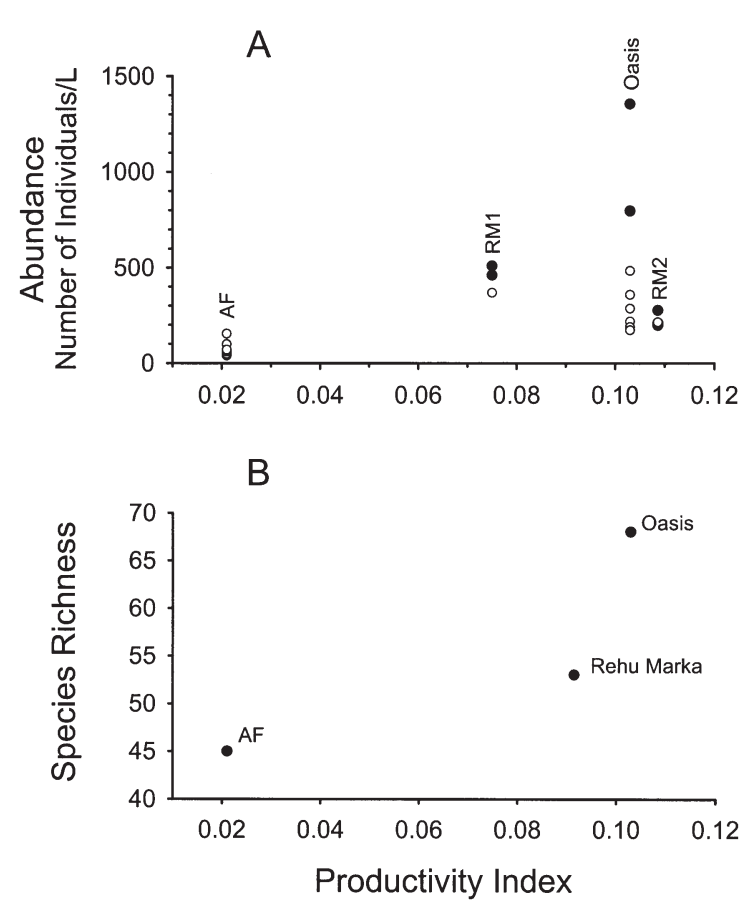

Fig. 12. (A) Abundance-productivity ( $\mathrm{O}=$ qualitative samples, - = quantitative samples) and (B) species richness-productivity relationships for Southern East Pacific mussel bed communities. Species richness is incidence-based coverage estimate. AF: Animal Farm; RM: Rehu Marka 
correlation (Pearson product-moment, $p>0.05$ ) in their abundances within quantitative samples.

Oasis was also characterized by size-frequency distributions of common invertebrate taxa that included larger size classes and consistently higher proportions of the smallest size classes than were found at Rehu Marka, supporting the idea that Oasis is a slightly more mature and more hydrothermally active mussel bed than Rehu Marka.

Coincident high levels of recruitment of limpets (Lepetodrilus elevatus), leptostracans (Dahlella caldariensis) and mussels (Bathymodiolus thermophilus) at Oasis and Rehu Marka raise the issue of how these recruitment levels could be sustained. The limpet has a non-planktotrophic larval stage (Lutz 1988), and there is some evidence that gene flow data are consistent with limited dispersal in this species (Craddock et al. 1997). Leptostracans brood their eggs, which hatch into juveniles, and dispersal is clearly limited in this taxon. Thus for both the limpet and the leptostracan, high levels of recruitment within discrete fields may reflect high levels of self-sustaining reproductive activity within populations at each field. Mussels, however, are presumed to have dispersive, planktotrophic larvae (Lutz et al. 1980) and have been shown to exhibit a high degree of gene flow (Vrijenhoek 1997). These factors argue for a regional-scale pool of competent mussel larvae, not unlike the seasonal situation in shallow-water ecosystems. It is remarkable that vent mussel larvae in the deep-sea water column are either so abundant or so well-corralled by circulation patterns and behavioral responses that they colonize mussel beds in large numbers. High abundances of mussel post-larvae and small juveniles were also observed at Lucky Strike mussel beds (Van Dover \& Trask 2000) and at $9^{\circ} 50^{\prime} \mathrm{N}$ mussel beds (Van Dover, unpubl. data). Although each sampling effort is itself a snapshot, consistently high abundances of mussel post-larvae in every sample of adult vent mussels regardless of geographic location, point to a prodigious ability of planktotrophic Bathymodiolus spp. larvae to locate small islands of hydrothermal activity in a vast ocean. If high abundances of post-larvae and small juvenile $B$. thermophilus continuously colonize active mussel beds, as I cautiously infer from my snapshot sampling, then the size-frequency distributions of mussels at Oasis and Rehu Marka (Fig. 4) are consistent with heavy consumption of the smaller size classes by predators such as the galatheid squat lobster Munidopsis subsquamosus or the crab Bythograea thermydron, which are frequently observed associated with mussel beds but were rarely captured in my samples. Heavy predation on recruits at vents has also been postulated, based on colonization experiments (Van Dover et al. 1988, Mullineaux et al. 1998). Other factors might also account for the apparent low success of the recruits, including competition or migration during growth to regions not sampled.

The distance between Animal Farm to the south and the more northern Oasis and Rehu Marka vent fields $(\sim 130 \mathrm{~km})$ is extremely unlikely to account for the differences in the community structure observed between these 2 regions. Species lists from robust vent sites separated by much greater distances in the eastern Pacific are quite similar (Desbruyéres \& Segonzac 1997), and there is no obvious geological or hydrographic feature that might serve as a barrier or filter to dispersal between Animal Farm and Oasis/Rehu Marka. Abiotic and biotic features of the Animal Farm field clearly indicate that it is in a waning stage: it has a depauperate invertebrate biomass, a large number of dead mussels, no significant indication of active hydrothermalism, supports a large number of scavenging animals, and has been invaded by non-vent deepsea taxa. Unique to the Animal Farm field are a number of isopods more usually associated with the non-vent deep sea, including Eurycope sp., which made up nearly $6 \%$ of the total abundance of individuals. Ophiuroids (Ophiura nov. sp.), which are generally thought to be rare or absent at vents because of their lack of circulatory and nephridial systems (Grassle 1986) and exposure of tissues to toxic chemistry (sulfides and metals) via their water-vascular systems (Tunnicliffe 1991), accounted for about $20 \%$ of the total abundance of individuals at Animal Farm, and of these, $\sim 50 \%$ were juveniles with test diameters $<1 \mathrm{~mm}$. Ophiura nov. sp. was also collected in fewer numbers at Oasis and Rehu Marka, but most individuals were $>1 \mathrm{~mm}$ diameter (Fig. 11). Among the polychaete taxa of Animal Farm, the polynoid Iphionella risensis was conspicuous by its abundance and its status as the only polynoid species in the community. In contrast, at Oasis and Rehu Marka, I. risensis cooccurred with 5 other polynoid species. At Animal Farm, a maldanid polychaete of uncertain identity (cf. Nicomache arwidssoni) was dominant over Amphisamytha galapagensis and Archinome rosacea, the common polychaetes at Oasis and Rehu Marka, and there was a complete absence of lepetodrilid limpets. The scavenging and/or predatory gastropod Phymorhynchus sp. was abundant throughout the Animal Farm field (Van Dover pers. obs.), although its numbers within the mussel bed samples do not show this. Phymorhynchus sp. has been implicated as a species associated with dying vent fields (Desbruyères 1995). Perhaps most indicative of the waning condition of the Animal Farm field was the complete absence of any post-larval mussels. This contrasts with post-larval and juvenile $(<5 \mathrm{~mm})$ mussel abundances at Rehu Marka and Oasis that were 4 times greater than the adults 
(Oasis, 1023 recruits vs 261 adults; Rehu Marka, 691 recruits vs 163 adults). The absence of mussel recruits at Animal Farm could be attributed to lack of a chemical settlement cue within the vent field or to absence of larvae in the overlying water column.

Surprisingly, the Animal Farm mussel bed community is as diverse as that of Oasis and Rehu Marka. This is accounted for by the much lower abundances but more even distribution of individuals among taxa at Animal Farm than at Oasis and Rehu Marka. In addition, while the waning fluid flux and microbial production may no longer support some of the typical vent taxa at Animal Farm, low levels of otherwise toxic sulfide allow non-vent taxa to invade the field, helping to maintain high levels of diversity.

\section{Comparison of southern East Pacific Rise, Mid-Atlantic Ridge, and intertidal mussel bed communities}

At the species level, there was $100 \%$ non-overlap between southern East Pacific Rise and the MidAtlantic Ridge mussel bed communities (this study, and Van Dover \& Trask 2000). Lucky Strike mussel beds on the MAR were numerically dominated by swimming crustaceans (ostracods, amphipods, copepods), while SEPR mussel beds were numerically dominated by amphipods, tube-dwelling polychaetes (particularly Amphisamytha galapagensis), and 2 species of lepetodrilid limpets.

Invertebrate diversity within mussel beds at Lucky Strike on the MAR, expressed as true species richness using incidence-based coverage estimators (28 species), was $50 \%$ or less than that found at the robust SEPR mussel beds of Oasis (68 species) and Rehu Marka (53 species). Oasis and Rehu Marka in turn have ICE-estimated true species richness lower than that found in an intertidal mussel bed community along the south-central Alaskan coast (77 species). Using a variety of diversity indices that take into account abundance data (Table 6), the Mid-Atlantic Ridge mussel bed community at Lucky Strike is highlighted as having lowest diversity. Each diversity index provides different information. Fisher's $\alpha$ is a number close to that of species expected to represented by only a single (i.e. rare) individual (Hayek \& Buzas 1997). The nearly equal values of Fisher's $\alpha$ at SEPR and intertidal mussel beds reflects similar numbers of species represented by small numbers of individuals. Lucky Strike had a relatively small proportion of singleton species compared to SEPR and the Alaskan mussel beds. Simpson's index is the probability that 2 individuals chosen at random from a sample belong to the same species (Hayek \& Buzas 1997). The high value of Simpson's index at the Animal Farm mussel bed community (8.52) indicates that individuals were more concentrated in proportionally fewer species than at the other fields. A relatively low value for Simpson's index at Lucky Strike (3.5) suggests that abundances were more evenly spread across a greater proportion of the total number of species within these mussel beds than elsewhere. Shannon's index $\left(H^{\prime}\right)$ provides a measure of uncertainty in the identity of an individual pulled randomly from a sample (Hayek \& Buzas 1997), with low $H^{\prime}$ indicating a fairly high certainty of outcome (i.e. low diversity). $H^{\prime}$ is thus insensitive to rare (especially singleton) species, and is not a good measure for discriminating this aspect of community structure. Southern East Pacific Rise vent mussel bed communities and the Alaskan intertidal mussel bed community had similar $H^{\prime}$ values (2.13 to 2.47$)$. $H^{\prime}$ for the mussel bed community at Mid-Atlantic Ridge mussel bed community at Lucky Strike was low (1.47). $H^{\prime}$ values at the mussel beds studied here are all well below those reported for non-vent deep-sea soft-sediment communities $\left(H^{\prime}=5.7\right.$ to 6.0: Grassle \& Maciolek 1992, Vanreusel et al. 1997), but within the range reported for intertidal mussel beds $\left(H^{\prime}=1.2\right.$ to 3.2 : Iwasaki 1995, Seed 1996, Tsuychiya \& Nishihira 1985).

While it is impossible to explain definitively why there was low species richness at Lucky Strike compared to species richness at SEPR mussel beds, there are several possibilities. First, the Atlantic Basin is younger than the Pacific Basin and the Mid-Atlantic Ridge is a younger spreading center system than the East Pacific Rise, resulting in less time for accumulation of species in the Atlantic system. The Lucky Strike field at $1700 \mathrm{~m}$ is also shallower than the SEPR fields $(2600 \mathrm{~m})$. There may be physiological and/or dispersal barriers that limit invasion of the shallow site by deepwater species; pressure tolerances of larvae have been implicated in controlling distributions of adult deepsea invertebrates (Tyler \& Young 1988). Productivity may be lower at Lucky Strike due to relatively lower concentrations of reduced compounds available for sulfide-based chemoautotrophic organic synthesis. Sulfide concentrations in end-member, 200 to $300^{\circ} \mathrm{C}$ vent fluids at Lucky Strike are on the order of 1.4 to $4.6 \mathrm{mM} \mathrm{kg}^{-1}$ (von Damm et al. 1998). This contrasts with values of $11 \mathrm{mM} \mathrm{kg}$ for $350^{\circ} \mathrm{C}$ end-member fluids at Oasis vents (von Damm pers. comm.). Greater productivity can support a larger number of species and certainly a larger biomass (Wright et al. 1993). Preliminary evidence of this relationship within vent habitats was seen on a local scale in the positive relationship of productivity and invertebrate abundance and species richness at SEPR vents, whereby the waning Animal Farm site supports a much lower abundance and species richness than the more productive Oasis and Rehu 
Marka sites (Fig. 12). Sampling of additional mussel beds with multiple levels of productivity needs to be undertaken to fully resolve this issue. Finally, spacing between vents on the slow-spreading Mid-Atlantic Ridge is greater than that on the ultra-fast-spreading southern East Pacific Rise (Baker et al. 1995). While greater spacing may result in greater isolation and more opportunities for speciation, the ephemeral nature of vents dictates dispersal and, where distances between vent fields are large, the likelihood of extinction may limit species richness (Van Dover 1995, Van Dover \& Trask 2000). None of these possibilities is exclusive.

\section{CONCLUSIONS}

Within mussel beds of active hydrothermal fields (Oasis and Rehu Marka) on the southern East Pacific Rise, invertebrate species composition is similar within sampling sites separated by tens of meters and between sampling methods (quantitative versus qualitative). Species composition is also similar between southern East Pacific Rise vent fields separated by $850 \mathrm{~m}$, but the relative abundances differ. As in intertidal mussel beds, active vent mussel beds are numerically dominated by a small number of taxa. A majority of the species found at active southern East Pacific Rise vents have been described from sites as distant as $13^{\circ} \mathrm{N}$ on the East Pacific Rise, indicating that the vent faunas along this length of ridge axis comprise a single biogeographic province. The invertebrate fauna associated with mussel beds of the waning vent field (Animal Farm) was distinctive in its low biomass, low abundance, lack of recruits, and the invasion of the vent field by non-vent, deep-sea taxa. Species richness within mussel beds at southern East Pacific Rise hydrothermal vents is higher than that found in mussel beds at Lucky Strike on the Mid-Atlantic Ridge. By continuing to resolve geographical and temporal variation in species richness and species composition within mussel bed communities at a variety of local and regional scales, it will be possible to address broader issues relating to the evolution and biogeography of vent faunas.

Acknowledgements. Samples from the southern East Pacific Rise were collected using RV 'Atlantis' and DSV 'Alvin' under the leadership of Captain Gary Chiljean and Expedition Leader Dudley Foster. Linda Popels and Elizabeth Boyle assisted in sample processing at sea. Ashley Hall, Sarah Sivers and Allison Trump helped with size-frequency measures. I am especially grateful to taxonomists who graciously assisted in species identifications: Jim Blake (non-polynoid polychaetes), Scott France (amphipods), Robert Hessler (isopods), Amélie Scheltema (aplacophorans), Gordon Pater- son and Paul Tyler (ophiuroids), and Dick Van Harten (ostracods). Cheryl Bright of the Smithsonian Institution provided access to polynoid collections deposited by Marian Pettibone and others. Rom Lipcius provided valued advice regarding analytical procedures and Cheryl Jenkins edited the manuscript. This manuscript benefitted greatly from the editorial advice of Ron Karlson and anonymous reviewers. Funding for this research was provided by the NSF Division of Ocean Sciences, Biological Oceanography.

\section{LITERATURE CITED}

Archambault P, Bourget E (1999) Influence of shoreline configuration on spatial variation of meroplanktonic larvae, recruitment and diversity of benthic subtidal communities. J Exp Mar Biol Ecol 238:161-184

Ault TR, Johnson CR (1998) Spatial variation in the fish species richness on coral reefs: habitat fragmentation and stochastic structuring processes. Oikos 82:354-364

Auzende JM, Ballu V, Batiza R, Bideau D and 7 others (1996) Recent tectonic, magmatic, and hydrothermal activity on the East Pacific Rise between $17^{\circ} \mathrm{S}$ and $19^{\circ} \mathrm{S}$ : submersible observations. J Geophys Res 101(B8):17995-18010

Baker ET, German CR, Elderfield H (1995) Hydrothermal plumes over spreading-center axes: global distributions and geological inferences. In: Humphris SE, Zierenberg RA, Mullineaux LS, Thomson RE (eds) Seafloor hydrothermal systems: physical, chemical, and geochemical interactions. American Geophysical Union, Washington, DC, p 47-71

Caley MJ, Schluter D (1997) The relationship between local and regional diversity. Ecology 78:70-80

Chao A, Ma MC, Yang MCK (1993) Stopping rules and estimation for recapture debugging with unequal failure rates. Biometrika 80:193-201

Connell JH (1972) Community interactions on marine rocky intertidal shores. Annu Rev Ecol Syst 3:169-192

Connell JH (1975) Some mechanisms producing structure in natural communities: evidence from field experiments. In: Cody MS, Diamond JM (eds) Ecology and evolution of communities. Harvard University Press, Cambridge, MA, p 460-490

Cornell HV, Karlson RH (1996) Species richness and reefbuilding corals determined by local and regional processes. J Anim Ecol 65:233-241

Colwell RK (1997) EstimateS: statistical estimation of species richness and shared species from samples. Version 5. User's Guide and application published at: http://viceroy. eeb.uconn.edu/estimates

Craddock C, Lutz RA, Vrijenhoek RC (1997) Patterns of dispersal and larval development of archaeogastropod limpets at hydrothermal vents in the eastern Pacific. J Exp Mar Biol Ecol 210:37-51

Desbruyères D (1995) Temporal variations of deep-sea hydrothermal communities at $13^{\circ} \mathrm{N} / \mathrm{EPR}$. InterRidge News 4:6-10

Desbruyères D, Segonzac M (1997) Handbook of hydrothermal vent fauna. Éditions IFREMER, Brest

Embley RW, Lupton JE, Massoth G, Urabe T and 6 others (1998) Geological, chemical, and biological evidence for recent volcanism at $17.5^{\circ} \mathrm{S}$; East Pacific Rise. Earth Planet Sci Lett 163:131-147

Fouquet Y, Auzende JM, Ballu V, Batiza R and 6 others (1994) Variabilité des manifestations hydrothermales actuelles le long d'une dorsale ultra-rapide: exemple de la Dorsale Est Pacifique entre $17^{\circ} \mathrm{S}$ et $19^{\circ} \mathrm{S}$ (campagne NAUDUR). CR 
Acad Sci Sér II A Sci Terre Planetes 319:1399-1406

Fustec A, Desbruyères D, Juniper SK (1987) Deep-sea hydrothermal vent communities at $13^{\circ} \mathrm{N}$ on the East Pacific Rise: microdistribution and temporal variations. Biol Oceanogr 4:121-164

Geistdoerfer P, Auzende JM, Batiza R, Bideau D and 5 others (1995) Hydrothermalisme et communautés animales associées sur la dorsale du pacifique oriental entre $17^{\circ} \mathrm{S}$ et $19^{\circ} \mathrm{S}$ (campagne NAUDUR, décembre 1993). CR Acad Sci Sér II A Sci Terre Planetes 320:47-54

Grassle JF (1986) The ecology of deep-sea hydrothermal vent communities. Adv Mar Biol 23:301-362

Grassle JF, Maciolek N (1992) Deep-sea species richness: regional and local diversity estimates from quantitative bottom samples. Am Nat 139:313-341

Grassle JF, Brown-Leger LS, Morse-Porteous L, Petrecca R, Williams I (1985) Deep-sea fauna of sediments in the vicinity of hydrothermal vents. Bull Biol Soc Wash 6:443-452

Hayek LA, Buzas MA (1997) Surveying natural populations. Columbia University Press, New York

Hessler RR, Smithey WM Jr, Keller CH (1985) Spatial and temporal variation of giant clams, tubeworms and mussels at deep-sea hydrothermal vents. Bull Biol Soc Wash 6: 411-428

Hessler RR, Smithey WM, Boudrias MA, Keller CH, Lutz RA, Childress JJ (1988) Temporal change in megafauna at the Rose Garden hydrothermal vent (Galápagos Rift; eastern tropical Pacific). Deep-Sea Res 35:1681-1709

Iwasaki K (1995) Comparison of mussel bed community between two intertidal mytilids Septifer virgatus and Hormomya mutabilis. Mar Biol 123:109-119

Lee SM, Chao A (1994) Estimating population size via sample coverage for closed capture- recapture models. Biometrics 50:88-97

Lintas C, Seed R (1994) Spatial variation in the fauna associated with Mytilus edulis on a wave- exposed rocky shore. J Molluscan Stud 60:165-174

Losos JB (1996) Phylogenetic perspectives on community ecology. Ecology 77:1344-1354

Lutz RA (1988) Dispersal of organisms at deep-sea hydrothermal vents: a review. Oceanol Acta (Spec Vol): 23-29

Lutz RA, Jablonski D, Rhoads DC, Turner RD (1980) Larval dispersal of a deep-sea hydrothermal vent bivalve from the Galápagos Rift. Mar Biol 57:127-133

Lutz RA, Fritz LW, Rhoads DC (1985) Molluscan growth at deep-sea hydrothermal vents. Bull Biol Soc Wash 6: 199-210

Menge BA, Sutherland JP (1976) Species diversity gradients: synthesis of the roles of predation, competition and temporal heterogeneity. Am Nat 110:351-369

Mullineaux LS, Mills SW, Goldman E (1998) Recruitment variation during a pilot colonization study of hydrothermal vents $\left(9^{\circ} 50^{\prime} \mathrm{N}\right.$, East Pacific Rise). Deep-Sea Res 45: $441-464$

Page HM, Fiala-Médioni A, Fisher CR Childress JJ (1991) Experimental evidence for filter-feeding by the hydrothermal vent mussel, Bathymodiolus thermophilus. Deep-Sea Res 38:1455-1461

Paine RT (1974) Intertidal community structure: experimental studies on the relationship between a dominant competitor and its principal predator. Oecologia 15:93-120

Petraitis PS, Latham RE (1999) The importance of scale in testing the origins of alternative community states. Ecology 80:429-442

Renard V, Hekinian R, Francheteau J , Ballard RD, Backer H (1985) Submersible observations at the axis of the ultrafast-spreading East Pacific Rise $\left(17^{\circ} 30^{\prime}\right.$ to $\left.21^{\circ} 30^{\prime} \mathrm{S}\right)$. Earth
Planet Sci Lett 75:339-353

Ricklefs RE, Schluter D (1993) Species diversity in ecological communities: historical and geographical perspectives. The University of Chicago Press, Chicago

Schlacher TA, Newell P, Clavier J, Schlacher-Hoenlinger MA, Chevillon C, Britton J (1998) Soft-sediment benthic community structure in a coral reef lagoon-the prominence of spatial heterogeneity and 'spot endemism'. Mar Ecol Prog Ser 174:159-174

Seed R (1996) Patterns of biodiversity in the macro-invertebrate fauna associated with mussel patches on rocky shores. J Mar Biol Assoc UK 76:203-210

Sousa W (1979a) Disturbance in marine intertidal boulder fields: the non-equilibrium maintenance of species diversity. Ecology 60:1225-1239

Sousa W (1979b) Experimental investigations of disturbance and ecological succession in a rocky intertidal alagal community. Ecol Monogr 49:227-254

Svane I, Setyobudiandi I (1996) Diversity of associated fauna in beds of the blue mussel Mytilus edulis L.: effects of location, patch size, and position within a patch. Ophelia 45: $39-53$

Tsuchiya M, Nishihira M (1985) Islands of Mytilus edulis as a habitat for small intertidal animals; effect of island size on community structure. Mar Ecol Prog Ser 25:71-81

Tunnicliffe V (1991) The biology of hydrothermal vents: ecology and evolution. Oceanogr Mar Biol Annu Rev 29: 319-407

Tyler PA, Young CM (1988) Temperature and pressure tolerances in dispersal stages of the genus Echinus (Echinodermata: Echinoidea): prerequisites for deep-sea invasion and speciation. Deep-Sea Res 45:253-277

Underwood AJ (1984) Vertical and seasonal patterns in competition for microalgae between intertidal gastropods. Oecologia 64:211-222

Underwood AJ (2000) Experimental ecology of rocky intertidal habitats: what are we learning? J Exp Mar Biol Ecol 250:51-76

Underwood AJ, Petraitis PS (1993) Structure of intertidal assemblages in different locations: How can local processes be compared? In: Ricklefs RE, Schluter D (eds) Species diversity in ecological communities: historical and geographical perspectives. The University of Chicago Press, Chicago, p 39-51

Underwood AJ, Denley EJ, Moran MJ (1983) Experimental analysis of the structure and dynamics of mid-shore rocky intertidal communities in new South Wales. Oecologia 56: 202-219

Underwood AJ, Chapman MG, Connell SD (2000) Observations in ecology: you can't make progress on processes without understanding patterns. J Exp Mar Biol Ecol 250: 97-115

Van Dover CL (1995) Ecology of Mid-Atlantic Ridge hydrothermal vents. Spec Publ Geol Soc Lond 87:257-294

Van Dover CL, Trask J (2000) Diversity at deep-sea hydrothermal vent and intertidal mussel beds. Mar Ecol Prog Ser 195:169-178

Van Dover CL, Berg CJ, Turner RD (1988) Recruitment of marine invertebrates to hard substrates at deep-sea hydrothermal vents on the East pacific Rise and Galápagos Spreading Center. Deep-Sea Res 35:1833-1849

Vanreusel A, Van den Bosche I, Thiermann F (1997) Freeliving marine nematodes from hydrothermal sediments: similarities with communities from diverse reduced habitats. Mar Ecol Prog Ser 157:207-219

Von Damm KL, Bray AM, Buttermore LG, Oosting SE (1998) The geochemical controls on vent fluids from the Lucky 
Strike vent field, Mid-Atlantic Ridge. Earth Planet Sci Lett 160:521-536

Vrijenhoek RC (1997) Gene flow and genetic diversity in naturally fragmented metapopulations of deep-sea hydrothermal vent animals. J Hered 88:285-293

Wishart D (2000) Clustan graphics. Clustan Ltd, Edinburgh

Editorial responsibility: Ronald Karlson (Contributing Editor), Newark, Delaware, USA
Wright DH, Currie DJ, Maurer BA (1993) Energy supply and patterns of species richness on local and regional scales. In: Ricklefs RE, Schluter D (eds) Species diversity in ecological communities: historical and geographical perspectives. The University of Chicago Press, Chicago, p 66-74

Submitted: June 5, 2000; Accepted: May 19, 2001

Proofs received from author(s): March 8, 2002 